\title{
Korešpondencia Jána Levoslava Bellu a Richarda Straussa
}

\section{Zuzana Godárová - Vladimír Godár}

Domáca (slovenská či československá) kultúra sa začala oboznamovat’ s osobnost’ou a dielom Jána Levoslava Bellu (1843 - 1936) v 20. rokoch 20. storočia. Po skončení 1. svetovej vojny a vzniku Československej republiky existoval hiátus medzi kultúrnou i hospodárskou úrovňou príslušníkov českého a slovenského národa, ktorý bol spôsobený hiátom minulostí oboch národov, ktoré mali tvorit’ piliere nového štátneho útvaru. Novovzniknutý štát si začal vytvárat’ novú kultúrnu identitu na báze modernej myšlienky československého národa, ktorá mala zabezpečit’ obom národom širšiu historickú perspektívu. Tento koncept prejavil svoje slabiny v krízových obdobiach politického vývoja Európy, a napokon bol dvakrát odmietnutý: jeho prvé odmietnutie spôsobil tlak nacizmu v období po Mníchovskej dohode v rokoch 1938 a 1939, ktorý smeroval k vytvoreniu okliešteného protektorátu Čechy a Morava a Slovenskej republiky v marci 1939; dôsledkom druhého odmietnutia bolo nenásilné rozdelenie spoločného štátu do dvoch samostatných republík po páde komunistického zriadenia v novembri roku 1989, k čomu došlo 1. 1. 1993.

Vznik Československej republiky si vyžadoval sústredenie intelektuálnych síl, ktoré si uvedomovali rozsah úloh spätých s myšlienkou budovania novej štátnosti. Dominantnú úlohu tu zohrala nepochybne česká inteligencia, kedž̌e rakúsko-mad’arské vyrovnanie spôsobilo násilné zbrzdenie vývojových ambícií Slovákov, ktorí si začali uvedomovat’ svoju národnú identitu v dôsledku činnosti L’udovíta Štúra a jeho priaznivcov počas 40. rokov 19. storočia. Hlavným iniciátorom tvorby kultúrnej identity občanov Československa sa preto stali zväčša príslušníci českej humanitnej i ekonomicko-hospodárskej inteligencie.

Ján Levoslav Bella bol od roku 1881 (teda od 38. roku života) aktívny ako tažisková osobnost' hudobného života nemeckej časti sedmohradskej Sibine. Po odchode do výslužby koncom roku 1917 zotrval na poste riaditela sibinského Hudobného spolku, ale roku 1921 sa ako 78-ročný odhodlal na presídlenie do Viedne, kde v tej dobe žili obe jeho deti. Tu sa zrodila postupne myšlienka návratu Bellu k vlastnému národu, kedže predstavoval vlastne jediného slovenského hudobníka, ktorý mohol pôsobit’ ako t’ažisková osobnost' rodiacej sa slovenskej hudobnej kultúry. Túto predstavu Bel- 
lovho návratu do domoviny začal uskutočňovat' bankový úradník a klavirista Gustáv Koričánsky (1886 - 1947), Bellov starý známy a priatel’ ešte zo sibinských rokov, Jaroslav Jindra (1890 - 1970), ktorý bol tajomníkom československého vyslanectva vo Viedni a dirigentom speváckeho spolku Lumír, budovatel'ská osobnost' Miloš Ruppeldt (1881 - 1943), moravský rodák a kňaz, profesor teologickej fakulty dr. Alois Kolísek (1868 - 1931) a prof. dr. Dobroslav Orel (1870 - 1942), zakladatel'ská osobnost' slovenskej hudobnej vedy a rektor Univerzity Komenského.

Hlavnými iniciátormi Bellovho návratu do rodnej zeme, ktorý sa napokon udial v marci 1928, sa stali Koričánsky, Ruppeldt, Kolísek a Orel. Opis vzájomnej korešpondencie Miloša Ruppeldta a Jána Levoslava Bellu z rokov 1924 - 1928 vyšiel v štúdii Zdenka Nováčka. ${ }^{1}$ Dobroslav Orel vydal roku 1924 základnú monografiu Jána Levoslava Bellu. ${ }^{2}$ Od tých čias je Bellov zakladatel'ský význam pre slovenskú kultúru pravidelne reflektovaný, jeho dielo sa stáva súčastou novodobej slovenskej hudobnej kultúry. Starostlivost' oň vyvrcholila projektom Súborného vydania diela Jána Levoslava Bellu, ktorý sa začal realizovat’ roku 1997 v Národnom hudobnom centre (od roku 1999 Hudobné centrum).

Dobroslav Orel uverejnil vo svojej publikácii aj pramenné prílohy: Bellovu autobiografiu a korešpondenciu (Bellove listy L. Procházkovi, F. Urbánkovi, K. Abrányimu, Listy L. Procházku Bellovi a listy Richarda Straussa Bellovi). ${ }^{3}$ Tieto listy v mnohom osvetl'ujú umelecké i ludské postoje, ako aj názory korešpondujúcich.

Predmetom nasledujúcej štúdie je vlastne zverejnenie písomných správ, osvetlujúcich vzt’ah a umelecké názory Jána Levoslava Bellu a Richarda Straussa. Ich vzájomný kontakt sa podla listových svedectiev začal v auguste 1888 a vyvrcholil uvedením Straussovej vokálno-symfonickej kompozície Wanderers Sturmlied op. 14 pod Bellovou dirigentskou taktovkou v Sibini a uvedením Bellovej symfonickej básne Osud a ideál pod Straussovou taktovkou v Eisenachu (22. 6. 1890). Tento dokument ostáva istým dejinným torzom, ale aj v tejto podobe má pre nás neocenitel'nú hodnotu. Zachovaný celok pozostáva zo štrnástich textov, ktoré tu chceme po prvýkrát publikovat’ v úplnosti v pôvodnej podobe a v slovenskom preklade. Nemáme k dispozícii pôvodné pramene, ale len už skôr publikované texty ich vzájomnej korešpondencie. Prvé kontakty oboch skladatel'ov a dirigentov sa začínajú v lete 1888, ked'Hanuš Wihan, violončelista Českého kvarteta, ktoré koncertovalo v sezóne 1887/1888 v Sibini, sprostredkoval zaslanie Bellovej Klavírnej sonáty Richardovi Straussovi s prosbou o pomoc s predvedením tohto diela. ${ }^{4}$ Bella mal v čase tohto prvého kontaktu 45 rokov a v sibinskom prostredí pôsobil už siedmy rok. Richard Strauss (1864 - 1949), vychádzajúca skladatel'ská a dirigentská hviezda nemeckej hudby, mal 24 rokov a absolvoval už prvé významné autorské aj interpretačné úspechy $v$ nemeckej oblasti.

Európska muzikológia si z tejto korešpondencie dosial' všimla len formulácie Straussových názorov, týkajúce sa aktuálneho problému „programovej hudby“, ${ }^{5}$ bellovská komplementujúca čast' korešpondencie ostala nepovšimnutá.

Na tomto mieste teraz stručne uvedieme obsah jednotlivých písomností, druhá čast’ štúdie sprístupní všetky spomínané písomnosti v ich úplnosti.

\section{Richard Strauss Jánovi Levoslavovi Bellovi, Mníchov, 27. 8. $1888^{6}$}

Strauss d’akuje Bellovi za poslanie Klavírnej sonáty b mol, pokúsi sa nájst’ pre ňu interpreta, vystríha však, že Hans von Bülow to asi nebude. Ponúka mu tiež na uvedenie 
svoje už vydané diela: Violončelovú sonátu op. 6, Klavírne kvarteto c mol op. 13, Huslovú sonátu Es dur op. 18, piesne op. 10, 15, 17, 19 a zhudobnenie Goetheho Wanderers Sturmlied pre šest'hlasný zbor a orchester.

\section{Richard Strauss Jánovi Levoslavovi Bellovi, Mníchov, 2. 12. 18887}

Strauss sa s obdivom vyjadruje o Bellovom článku o Lisztovi, vidí v ňom priekopníka nových hudobných postojov, chápania „hudby ako výrazu“, a nie ako „znejúcich foriem“. Ďalej opisuje svoj umelecký prechod od symfonického cyklu k symfonickej básni. Ďakuje za angažovanost' vo veci naštudovania Wanderers Sturmlied a opisuje možné inštrumentačné retuše, ktoré závisia od vel'kosti zboru, kedže je nevyhnutné, aby bol zborový part nanajvýš zretel'ný.

\section{Ján Levoslav Bella: Goethe: Wanderers Sturmlied (Richard Strauss, Op. 14) ${ }^{8}$}

Bella poslal Straussovi svoj text, ktorý napísal pri príležitosti uvedenia jeho zhudobnenia Goetheho básne Wanderers Sturmlied, aby publikum „správne načúvalo" Straussovo dielo počas koncertu. Približuje poslucháčom okolnosti vzniku Goetheho básne, ako aj akési posolstvo básne, a prináša vysvetlenie paralelizmov medzi Goetheho poéziou a skladatel'ovou partitúrou, načrtáva zároveň možnost’ symbolickej interpretácie Straussovej inštrumentácie.

\section{Richard Strauss Jánovi Levoslavovi Bellovi, Mníchov, 16. 12. $1888^{9}$}

Strauss d’akuje Bellovi za úvahu o svojom diele Wanderers Sturmlied; je ňou nadšený, je to „najkrajšia kritika mojich diel, akú som kedy čítal." Tiež dúfa, že predvedenie Bellu uspokojilo a pýta si od Bellu zaslanie jeho kompozícií.

\section{Richard Strauss Jánovi Levoslavovi Bellovi, Mníchov, 21. 12. $1888^{10}$}

Opätovné vyjadrenie vd’aky za predvedenie diela Wanderers Sturmlied a prosby o zaslanie slúbených kompozícií.

\section{Richard Strauss Jánovi Levoslavovi Bellovi, Weimar, 25. 10. 188911}

Strauss si pýta zaslanie partitúry a orchestrálnych hlasov z Bellovej symfonickej básne - možno ju dokáže zaradit’ do svojich budúcich koncertov. Slúbuje, že vráti noty Klavírnej sonáty, ktorá by si zaslúžila pohodlnejšiu klavírnu sadzbu. Možno o ňu prejaví záujem Bernhard Stavenhagen, ${ }^{12}$ všeobecne však klaviristi neradi uvádzajú nové diela.

\section{Richard Strauss Jánovi Levoslavovi Bellovi, Viedeň, 3. 3. $1890^{13}$}

Strauss vyslovuje nádej, že sa mu podarí uviest’ Bellovo dielo v rámci štyroch abonentných koncertov Všeobecného nemeckého spolku hudobných umelcov v Eisenachu, závisí to aj od vyjadrenia hudobnej komisie. Osud a ideál Straussa zaujal originálnym jazykom, avšak nevie si rady s len tušeným programom. Súdobých skladatelov delí do dvoch skupín: pre jedných je hudba „výrazom“, pre druhých „znejúcou formou“. Prvá, „programová hudba“ je skutočná hudba, druhá, , absolútna hudba“ je prejavom zručnosti. Pravé určenie hudby pochádza od Wagnera a Liszta, pre ktorých je hudba „najdokonalejším výrazom hudobno-poetickej myšlienky", je to "jediná pravá hudba". Strauss je však bezradný pri uchopení Bellovej „programovej hudby“. Píše o sebe, že vo svojich aktuálnych dielach, v troch symfonických básňach (Macbeth, Don Juan 
a Smrt'a vykúpenie) zahodil staré haraburdie formy, aby nasledoval hudobno-poetickú myšlienku. ${ }^{14}$ Možno Bellovmu dielu uškodili neskoršie revízie, každopádne by sa chcel o umeleckej podstate skladby dozvediet' čosi viac.

\section{Richard Strauss Jánovi Levoslavovi Bellovi, Weimar , 19. 4. 1890'15}

Strauss oznamuje Bellovi, že Osud a ideál celkom určite zaznie počas zhromaždenia Všeobecného spolku hudobných umelcov v Eisenachu pod jeho taktovkou.

\section{Ján Levoslav Bella Richardovi Straussovi, Sibiň, 25. 4. 1890 16}

Bella sa snaží v tomto liste osvetlit' odraz svojho životného príbehu v symfonickej básni, ktorú nazval Osud a ideál. Pod ideálom treba chápat' "lásku, najkrajšiu formu života, lásku ako zakladatel'ku rodiny". Táto láska mu bola odopieraná podobne, ako bola odopieraná aj žene, ku ktorej tento cit prechovával a v ktorej sa napokon zlomila. Bella tieto pocity líči pomocou hudobných, takmer "wagnerovských“ leitmotívov, pričom v samotnej skladbe dochádza k zápasu protirečivých prvkov (z tohto hladiska je Osud a ideál vlastne akási symfonická inkarnácia battaglie). Jednotlivé témy a následné fázy skladby predstavujú etapy boja jedinca, ktorý však nevít’azí, ale zažíva monumentálnu frustráciu. Tento boj (zhustený oproti premiérovanej verzii) opisuje v štrnástich bodoch, ktoré spája s následnými fázami či epizódami svojej skladby. Doterajšie nedorozumenia boli iste výsledkom toho, že sa dostatočne nesnažil slovne vyjadrit' svoj skladatel'ský zámer. List obsahuje 16 notových príkladov, pomocou ktorých môže Strauss vniknút’ do esencie Bellovej symfonickej básne. ${ }^{17}$

\section{Richard Strauss Jánovi Levoslavovi Bellovi, Mníchov, 11. 7. 1890 ${ }^{18}$}

Strauss posiela Bellovi správu o koncerte v Eisenachu, kde dielo uviedol 22. mája 1890. Dielo sa vydarilo a zožalo potlesk. On sám si ho ozrejmil vd’aka programu, ktorý mu Bella poslal. Teraz mu už v úplnosti rozumie, avšak myslí si, že by poslucháč mal mat k dispozícii „presný básnický program“. Vyjadruje potešenie, že ako prvý uviedol Bellovo meno do pozornosti nemeckej verejnosti a zároveň Bellu vyzýva na skomponovanie nového diela, ktoré by mohol uviest'.

\section{Richard Strauss Jánovi Levoslavovi Bellovi, Weimar, 30.9. 1890 ${ }^{19}$}

V tomto liste Strauss zopakuje svoju prosbu k Bellovi o vytvorenie nového diela, ktoré by mohol uviest'.

\section{Franz Strauss Jánovi Levoslavovi Bellovi, Mníchov, 11. 2. $1893^{20}$}

Franz Strauss, otec Richarda, oznamuje Bellovi, že jeho syn sa po zotavení z choroby nachádza v Egypte. Zároveň mu d’akuje za analýzu synovho diela Wanderers Sturmlied.

\section{Richard Strauss Jánovi Levoslavovi Bellovi, Charlottenburg, 12. 10. $1899^{21}$}

V tomto liste Richard Strauss opisuje Bellovi pomery, ktoré vládnu v európskom opernom svete a prosí ho o zaslanie klavírneho výtahu nového Bellovho operného diela. List umožňuje datovat' dokončenie Bellovej opery Kováč Wieland, ked'že nepochybne ide o toto dielo. Strauss samotný sa necíti byt' dostatočne silný, aby prekonal obchodnícke maniere a sily, ktoré ovládajú dnešný operný svet. 
14. Richard Strauss Jánovi Levoslavovi Bellovi, Grand Hotel St. Moritz, St. Moritz-Dorf, 29. 1. $1912^{22}$

Strauss gratuluje Bellovi k talentovanému synovi Rudolfovi (1890 - 1973), ktorý v tejto dobe študoval vo Viedni skladbu u Eusebia Mandyczewského (1857 - 1929) a dirigovanie u Franza Schalka (1863 - 1931). Vyjadruje nádej, že sa všetci spolu stretnú, azda v Budapešti. Ernest Zavarský slovami Rudolfa dosvedčuje, že k tomuto stretnutiu došlo, ked' opisuje Straussovu snahu umiestnit’ Kováča Wielanda na javisko budapeštianskej opery:

"Strauss vzal môjho otca a mňa k riaditelovi budapeštianskej opery Raoulovi Maderovi, ktorému vyčítal v našej prítomnosti, že Budapešt' ešte nepredviedla operu môjho otca Kováč Wieland, ,kde sa teda má pán Bella so svojou operou obrátit', ked' sa o ňu nezaujíma ani operná scéna jeho užšej vlasti?' Mader na to slúbil, že presadí predvedenie opery. Môj otec si však chcel zadané dielo ešte raz prezriet', vyžiadal si materiál spät’ a z predvedenia nebolo nič. ${ }^{\prime 23}$

Torzo zachovanej vzájomnej korešpondencie Jána Levoslava Bellu a Richarda Straussa z rokov 1888 - 1912 dokumentuje zrod medzigeneračného priatel'stva dvoch služobníkov hudby, skladatelov, dirigentov a organizátorov hudobného života, ktorých životy oddel'ovalo 21 rokov. Sú svedectvom vzájomnej úcty i zvedavosti, ktorá sprevádzala hudbu k novým významovým svetom. Najpozoruhodnejšiu čast' tejto korešpondencie predstavujú dva autorské texty Jána Levoslava Bellu (3, 9), týkajúce sa chápania poetiky powagnerovskej hudby, novo nastol'ovaného ideálu programovej hudby, ale aj akési tvorivé krédo, s ktorým sa zveril mladší skladatel' staršiemu kolegovi (7). Nepochybne prináša však aj množstvo detailných informácií, ktoré nám približujú nielen postoje tvorivých umelcov, ale aj spoločenské pozadie ich práce. Podla svedectva Rudolfa Bellu sa obaja stretli u riaditel'a budapeštianskej opery Madera - pravdepodobne v roku 1912 - ked'sa Richard Strauss prihováral za inscenovanie Bellovej opery Kováč Wieland. K ich d’alšiemu (a pravdepodobne aj poslednému) osobnému stretnutiu došlo 11. 1. 1929 v Bratislave, ked' tu Richard Strauss dirigoval svoju hudobnú komédiu Der Rosenkavalier. Pri prvom kontakte mal Bella 45 rokov a Strauss 24, pri poslednom osobnom stretnutí mal Bella 85 rokov a Richard Strauss 64 rokov. Pripomeňme tu však ešte raz nezanedbatel'nú skutočnost', že Richard Strauss detailne poznal tri významné Bellove kompozície - Klavírnu sonátu b mol, symfonickú báseň Osud a ideál a operu Kováč Wieland - a všetkým sa snažil pomôct' k živej existencii. 
München, den 27. August 88

Neuhauserstr. 11/3

Sehr verehrter Herr College!

Haben Sie herzlichsten Dank für die liebenswürdige Übersendung Ihrer hochinteressanten Klaviersonate, die ich für ein höchst originelles, geistvolles, warm empfundenes Kunstwerk halte, dessen Bekanntschaft mir große Freude bereitet hat und welches entschieden würdig wäre, fleissig gespielt zu werden. Seien Sie versichert, dass ich mit Vergnügen das Meinige dazu beitragen werde, Ihrem Werke den Freundeskreis zu erwerben, den es verdient. Wenn Sie mir die Sonate noch eine Zeitlang überlassen wollen, werde ich jedenfalls die hervorragenden hiesigen Klavierspieler damit bekannt machen und einen davon zu bestimmen suchen, dieselbe öffentlich hier zu spielen. Ob es mir gelingen wird, Herrn von Bülow dafür zu interessieren, vermag ich Ihnen leider nicht zu versprechen. Sie wissen wohl, daß derselbe für ihm zugesandte, unbekannte oder von Freunden empfohlenen Novitäten ziemlich unzugänglich ist. Keinesfalls würde ich Ihnen raten, falls Sie ihn nicht persönlich gut kennen, ihm Ihr Stück zuzusenden, da Sie sich nur einen Refus holen würden. Wenn Sie mir vertrauen wollen, so verspreche ich Ihnen, bei passender Gelegenheit (die, wie berichtet, erst in einem halben Jahre da sein wird), ihn auf Ihr Werk aufmerksam zu machen, dies ist aber leider auch Alles, was ich thun kann. Ihr liebenswürdiger Wunsch, von meinen Compositionen, welche zur Aufführung zu bringen, hat mich sehr erfreut. Ich habe ausser meiner Cellosonate op. 6, ein Klavierquartett c-Moll, op. 13, und eine Violinsonate (Es-Dur) op. 18, ein Werk für 6 stimmigen gemischten Chor mit Orchester op. 14 „Wanderers Sturmlied“ von Goethe, ausser meinen Sinfonien op. 12 und op. 16, 4 Hefte Lieder op. 10, 15, 17 und 19 veröffentlicht. Wenn Sie einen guten Chor haben, würde mich eine Aufführung von „Wanderers Sturmlied“ sehr erfreuen. Alle meine Werke sind bei Jos. Aibl, München, erschienen. Indem ich Sie nochmals meiner aufrichtigsten Hochachtung vor Ihrer famosen Klaviersonate versichere, verbleibte ich mit herzlichen Gruss und Dank Ihr

ergebenster

Richard Strauss

2

München, den 2. December 88

Mein lieber, sehr verehrter Herr Bella!

Ihr reizend liebenswürdiger Brief hat mir ungeheure Freude bereitet. In erster Linie überraschte mich höchlichst der Einblick in Ihr Hermannstädter Musikleben, den Sie mir durch Ihren ausgezeichneten Lisztartikel vergönnt haben. Also nach Siebenbürgen muss man gehen, um eine stilvolle Aufführung des Prometheus zu hören? Unsere grossen Concertinstitute wälzen sich noch immer mit grunzendem Behagen in ewigen Wiederholungen von Judas Maccabäus, Elias, Paradies u. Peri herum und treiben unter der heuchlerischen Maske der Classikerverehrung den herrlichsten Kunstbummel, indem Sie Mozartsche und Beethovensche Sinfonien in einer Weise aufführen, dass jeder Classikerverehrer von tiefstem Herzensgrunde aus (nicht aus Bequemlichkeit) sich mit Grausen abwendet. - Wie wenige unserer heutigen, in edlem viersätzigen Formelwesen sich herumtreibenden Musiker haben 
Mníchov, 27. augusta 1888

Neuhauserstr. 11/3

Velavážený pán kolega!

Vyslovujem Vám najsrdečnejšiu vd’aku za láskavé zaslanie Vašej vel'mi zaujímavej Klavírnej sonáty, ktorú pokladám za nanajvýš originálne, duchaplné, srdečne precítené umelecké dielo, poznanie ktorého mi prinieslo velkú radost’ a ktoré by sa malo rozhodne často hrat'. Uistujujem Vás, že s potešením prispejem z mojej strany $k$ tomu, aby si Vaše dielo získalo okruh priatelov, ktorý si zaslúži. Ak mi Sonátu ešte nejaký čas ponecháte, v každom prípade s ňou oboznámim tunajších vynikajúcich klaviristov a pokúsim sa určit jedného z nich, ktorý by Sonátu zahral pre tunajšiu verejnost'. Žial', neviem Vám slúbit', či sa mi podarí zaujat' ňou pána von Bülow. Asi viete, že menovaný je pomerne neprístupný novinkám, ktoré mu boli poslané, neznáme alebo odporúčané priatel'mi. V žiadnom prípade by som Vám neradil, ak ho osobne dobre nepoznáte, aby ste mu Vaše dielo zaslali, pretože by ste si len privolali odmietnutie. Ak mi budete dôverovat', slubujem Vám, že ho pri vhodnej príležitosti (ktorá nastane, ako je uvedené, až o pol roka) upozorním na Vaše dielo, to je ale, žial', aj všetko, čo môžem urobit'. Vel'mi ma potešilo Vaše láskavé prianie uviest' niektoré z mojich kompozícií. Okrem Violončelovej sonáty, op. 6 som vydal Klavírne kvarteto c mol op. 13 a Huslovú sonátu (Es dur) op. 18, dielo pre šesthlasný miešaný zbor a orchester op. 14 Goetheho Wanderers Sturmlied, okrem mojich symfónií op. 12 a op. 16 aj 4 zošity piesní op. 10, 15, 17 a 19. Ak máte k dispozícii dobrý zbor, vel'mi by ma potešilo uvedenie Wanderers Sturmlied. ${ }^{24}$ Všetky moje diela vyšli vo vydavatel'stve Jos. Aibl v Mníchove. Znova Vás uist'ujúc o najúprimnejšom obdive k Vašej famóznej Klavírnej sonáte zostávam so srdečným pozdravom a vd’akou Váš

najoddanejší

Richard Strauss

\section{List Richarda Straussa Jánovi Levoslavovi Bellovi}

Mníchov, 2. decembra 1888

Môj milý, velavážený pán Bella!

Váš pôvabný láskavý list mi spôsobil obrovskú radost'. Predovšetkým ma nanajvýš prekvapil pohlad na Váš hudobný život v Sibini, ktorý ste mi dožičili Vaším vynikajúcim článkom o Lisztovi. Takže treba íst do Sedmohradska na to, aby sa dalo vypočut štýlové predvedenie Promethea? ${ }^{25}$ Naše vel'ké koncertné inštitúcie sa ešte stále blažene krochkajúc prevalujú vo večných reprízach Judáša Makabejského, Eliáša, Raj a Peri' ${ }^{26}$ a prevádzkujú pod pokryteckou maskou pocty klasikom najúžasnejšie umelecké korzo tým, že uvádzajú Mozartove a Beethovenove symfónie takým spôsobom, že sa každý milovník klasikov z hlbín srdca (nie z pohodlnosti) s hrôzou odvráti. - Ako málo našich dnešných hudobníkov, ponevierajúcich sa v ušlachtilej sústave pravidiel pre štvorčastovú formu, úplne pochopilo 
das Wesen unserer herrlichen Musik ganz begriffen. Unserer "Musik als Ausdruck“, nicht als Hanslicksche "tönende Form“!

Nach der Bekanntschaft mit Ihrem Lisztartikel freue ich mich, in Ihnen einen so echten, wahren Musiker begrüssen zu können, wie wir sie heute so notwendig brauchen und so selten finden.

Hinweg mit dem öden viersätzigen Formelwesen, dem seit der IX.-ten kein neuer Inhalt mehr entsprossen ist; der musikalisch poetische Inhalt muss künftig die Form bestimmen und darin ist Liszt, anknüpfend an Beethoven's Coriolan, Leonore III. etc., der Wegweiser für uns Jüngere gewesen.

Auch ich habe in der Sonaten-Form zu schaffen begonnen, jetzt habe ich in der Erkenntnis, daß in ihr nicht wahrhaft neues mehr zu sagen ist, mit ihr vollständig gebrochen und habe in zwei großen sinfonischen Dichtungen: Macbeth u. Don Juan (letztere nach Lenau's herrlicher Dichtung) mich ganz der Einsätzigkeit zugewandt in der Weise, daß der musikalisch poetische Inhalt meines Werkes die Form desselben schuf. Mit jedem neuen Werke sich die eigene Form zu geben $u$. trotzdem nicht formlos zu werden, ist allerdings mühsamer, als mit Hülfe des alten, nach allen Seiten hin bereits ausgeweiteten Sonatengerüstes eine leidliche Sinfonie zu schreiben. - Sie fragen mit Recht, warum ich mich Ihnen darüber so ausführlich mitteile? Weil Sie mich verstehen, das ersehe ich aus Ihrem Artikel; Sie haben jedenfalls Wagner's Broschüren über "Liszt sinfonische Dichtungen“, "Die Ouvertüre“ etc. gelesen! Aus Ihrer B-moll Sonate ersah ich so deutlich, wie ein wundervoller poetischer Inhalt nach der Erscheinung ringt, unter dem Bann der einengenden viersätzigen Sonatenformel (für Beethoven war sie größtenteils „Form", nämlich der einzig mögliche Ausdruck seiner Gedanken) nicht zu voller klarer Entwicklung gelangen kann. Drum wollen wir „Programmusik“ (nur im Munde der übelgesinnten ein schlechtes Wort) schreiben, denn nach meiner Ansicht hat Beethoven nur Programmusik geschrieben, wenn er uns auch den poetischen Vorwurf, der das Entstehen seines Werkes veranlaßte, nur sehr selten mitgeteilt hat. - Vielleicht geben Ihnen meine nur sehr unvollständigen Zeilen eine Anregung! Haben Sie schon Orchesterwerke geschrieben? Ich bitte Sie dringend um baldige Zusendung Ihrer mir in Aussicht gestellten Compositionen, die mich aufs höchste interessieren. -

Nun aber will ich Ihnen noch vielmals danken für die liebevolle Art, mit der Sie sich für meine Compositionen interessieren; ich freue mich herzlich, daß Sie u. Ihre Musiker u. Sänger sich so sehr mit meinem Sturmlied befreundet haben. Vielen, vielen Dank für die grosse Mühe, die Sie meinem Werke zugewendet haben. Hier noch eines! Das Sturmlied ist sehr stark instrumentiert und für einen sehr großen Chor berechnet.

Ich überlasse es nun ganz Ihrem eigenen künstlerischen Ermessen, eventuell im Orchesterparte herauszustreichen (besonders in den Trompeten und Posaunen), damit vor allem der Chor zur vollständigsten Deutlichkeit gelange. So könnte man ganz gut den 4., 5., 6. Takt nach F die Bläser ganz herauszustreichen unternehmen und erst im 7. Takt das ganze Orchester mit dem Es-Dur-Accord einfallen lassen. Die ff und f des Blechs werden Sie, glaube ich, sehr dämpfen müssen!

Wie gesagt, verfahren Sie hierin ganz nach eigenem Ermessen nach Massgabe der Grösse und Stärke Ihres Chors! Ich gebe Ihnen volle Freiheit! Es ist aber das erste, dass der Chor zu möglichster Deutlichkeit gelange!

Nun leben Sie wohl! Haben Sie nochmals tausend Dank für Ihre Freundlichkeit und schicken Sie mir bald Ihre Compositionen!

Mit den herzlichsten Grüssen 
podstatu našej nádhernej hudby. Našej,,hudby ako výrazu“, nie ako hanslickovskej„„znejúcej formy"!

Po tom, čo som sa oboznámil s Vaším článkom o Lisztovi, sa teším, že vo Vás môžem privítat takého rýdzeho, pravého hudobníka, akých dnes tak nutne potrebujeme a tak zriedkavo nachádzame.

Preč s jednotvárnou sústavou pravidiel pre štvorčast’ovú formu, z ktorej od 9. symfónie už nevyklíčil žiaden nový obsah; hudobno-poetický obsah musí v budúcnosti stanovovat formu a v tom bol Liszt, nadväzujúc na Beethovenovho Coriolana, Leonore III. ${ }^{27}$ atd'., ukazovatel'om smeru pre nás mladších.

Aj ja som začal tvorit’ v sonátovej forme, avšak teraz, ked'som spoznal, že v nej už skutočne niet čo nové povedat', som s ňou úplne skoncoval a obrátil som sa v dvoch vel'kých symfonických básňach: Macbeth a Don Juan ${ }^{28}$ (posledná zmienená vznikla podla Lenauovej nádhernej básne) úplne k jednočast’ovosti tým spôsobom, že hudobno-poetický obsah môjho diela vytvoril jeho formu. Avšak utvárat’ s každým novým dielom vlastnú formu, a napriek tomu sa nestat’ bezforemným, je namáhavejšie ako pomocou starej, na všetky strany rozšírenej sonátovej konštrukcie napísat' obstojnú symfóniu. - Právom sa pýtate, prečo sa Vám s tým tak podrobne zverujem? Pretože mi rozumiete, to vidím z Vášho článku; iste ste čítali Wagnerove brožúry O Lisztových symfonických básňach, O predohre ${ }^{29}$ atd'!! Z Vašej Sonáty $b$ mol som videl tak jasne, ako čarovný poetický obsah zápasí o zjavenie, pod kliatbou obmedzujúceho štvorčastového sonátového pravidla (pre Beethovena bolo zväčša "formou", totiž jediným možným výrazom jeho myšlienok) nemôže dospiet” k plnému jasnému vývoju. Preto chceme písat' „programovú hudbu“ (škaredý výraz iba v ústach zlomysel'ných), pretože podla mojej mienky Beethoven písal iba programovú hudbu, aj ked' nás s poetickou predlohou, ktorá podnietila vznik jeho diela, oboznámil len vel'mi zriedka. - Možno Vás povzbudia moje len vel'mi neúplné riadky! Už ste napísali nejaké orchestrálne diela? Naliehavo Vás prosím o skoré zaslanie vašich slúbených kompozícií, ktoré ma nanajvýš zaujímajú.

Chcem Vám však ešte mnohokrát pod’akovat' za láskavý spôsob, ktorým sa zaujímate o moje kompozície; srdečne sa teším, že ste sa Vy, Vaši hudobníci a speváci tak vel'mi spriatelili s mojím dielom Sturmlied. Vel'ká, vel'ká vd’aka za tú značnú námahu, ktorú ste venovali môjmu dielu. A ešte niečo! Dielo Sturmlied je vel'mi silne inštrumentované a počíta s vel'mi vel'kým zborom.

Nuž ponechávam úplne na Vaše vlastné umelecké uváženie prípadné škrty v orchestrálnom parte (najmä pri trúbkach a trombónoch), aby najmä zbor nadobudol čo najúplnejšiu zretel'nost'. Tak by sa dali celkom dobre úplne vyškrtnút' dychové nástroje v 4., 5., 6. takte po F a až v 7. takte nechat' nastúpit’ celý orchester s akordom Es dur. Myslím si, že budete musiet' vel'mi stlmit' ff a f plechových nástrojov!

Ako bolo povedané, postupujte v tom úplne podla vlastného uváženia podla vel'kosti a sily Vášho zboru! Dávam Vám úplnú vol'nost!! Najdôležitejšie však je, aby zbor nadobudol čo najväčšiu zretel'nost'!

Nuž majte sa dobre! Ešte raz tisíckrát vd’aka za Vašu láskavost’ a pošlite mi čoskoro Vaše kompozície!

S najsrdečnejšími pozdravmi 
P. S. Beiliegender Artikel aus der Köllner Zeitung ist der einzige, den ich gefunden habe. Eine sehr gute Kritik über das Sturmlied ist diesen Sommer im Fritzsche'schen Wochenblatt erschienen; ich schreibe heute noch um dieselbe nach Leipzig!

Von Buchstaben W bis X können die Trompeten auch gestrichen werden! etc.

3 Wanderers Sturmlied von Richard Strauss. Eine Analyse für Mitwirkende und Zuhörer von J. L. B. 1888

[Die Studie von Bella, die dem Autor eine solche „Freude“ bereitete, lautet:

Goethe: Wanderers Sturmlied.

Für sechsstimmigen Chor und grosses Orchester.

Komponiert

von

Richard Strauss.

Op. 14.]

Mit wahrer Begeisterung geht der Hermannstädter Musikverein daran, diese grossartige und ausserordentlich schwierige Chorkomposition des jüngsten deutschen Meisters seinem Publikum vorzuführen. Eine Reihe von eingehenden Proben hat den im Chor und im Orchester beteiligten Kräften den klaren Einblick in ein einzig dastehendes Stimmengeflecht eröffnet, und wir erwarten, dass die überquellende Fülle der so vielfach ineinander geschlungenen Tonbilder, mit denen sonst die erstmalige Wiedergabe verblüffen und verwirren müsste, auch vor solchen Zuhörern in plastischer Über- und Unterordnung auffallen wird, die vorher keine Probe zu diesem Werke anzuhören Gelegenheit hatten - aber im Geniessen von tiefer angelegter Konzertmusik geschult, vorher wenigstens von diesen flüchtigen Zeilen Kenntnis genommen haben werden.

Diese Vorbereitung ist schon hinsichtlich des poetischen Vorwurfes unerlässlich, den hier der Komponist nicht bloss äusserlich vertont, wie sich am Ende jeder Text in eine musikalische Zwangsjacke stecken liesse, sondern nach allen Richtungen ergänzend und vertiefend durch die Machtmittel der heutigen Tonkunst derartig zum lebendigen Dasein weckt, dass das dunkle und flüchtige Wort des Dichters zu einer unsere Seele unwiderstehlich erschütternden und erbebenden Wahrheit wird.

Wohl wenige werden sich dieses Gedichtes entsinnen - gar Wenige aber seine kühne und dunkle Sprache verstehen. Da nicht ein jeder Konzertbesucher mit den erforderlichen literarischen Hilfsmitteln versehen sein kann, so ist es Pflicht, vorher dem Gedichte selbst zum notwendigsten Verständnis zu verhelfen.

„Die Entstehung dieses Gedichtes“, - sagt Heinrich Viehoff, - „fällt in den Herbst oder in den Wintersanfang des Jahres 1771. Über die Stimmung, in der es entstand, hat uns Goethe selbst in ,Wahrheit und Dichtung' Mitteilungen gemacht. Friederike Brion hatte, nachdem er von der Universität zu Strassburg in seine Vaterstadt zurückgekehrt war, noch einmal an ihn geschrieben und auf eine Weise Abschied genommen, die ihm das Herz zerriss. ,Es war dieselbe Hand', schreibt Goethe, ,derselbe Sinn, dasselbe Gefühl, die sich zu mir, die sich an mir herangebildet hatten. Ich fühlte nun erst den Verlust, den sie erlitt, und sah keine Möglichkeit inn zu ersetzen, ja nur ihn zu lindern. Sie war mir ganz gegenwärtig; stets empfand ich, dass sie mir fehlte und was das Schlimmste war, ich konnte mir mein eigenes Unglück nicht verzeihen. Gretchen hatte man mir genommen, Anette mich verlassen, hier war ich zum erstenmal schuldig; ich hatte das schönste Herz in seinem Tiefsten verwundet und so war die Epoche einer düstern Reue, bei dem Mangel einer gewohnten erquicklichen Liebe, 
P. S. Priložený článok z novín Köllner Zeitung je jediný, ktorý som našiel. Vel'mi dobrá kritika na Sturmlied vyšla toto leto vo Fritzschovom týždenníku Wochenblatt; napíšem ešte dnes po ňu do Lipska!

Trúbky môžu byt' vyškrtnuté aj od písmena W po X! atd'.

3 Úvaha Jána Levoslava Bellu o Straussovom-Goetheho diele Wanderers Sturmlied (Wanderers Sturmlied von Richard Strauss.

Eine Analyse für Mitwirkende und Zuhörer von J. L. B. 1888.)

[Bellova štúdia, ktorá autorovi urobila takú „radost", má názov:

Goethe: Pútnikova pieseň v búrke

pre šesthhlasný zbor a vel'ký orchester.

Zložil

Richard Strauss.

Op. 14.]

Hudobný spolok v Sibini pristupuje s pravým nadšením k predvedeniu tejto vel'kolepej a mimoriadne obt’ažnej zborovej skladby najmladšieho nemeckého majstra svojmu publiku. Séria intenzívnych dôkladných skúšok otvorila silám zúčastneným v zbore a orchestri jasný pohlad na jedinečne jestvujúcu splet’ hlasov a očakávame, že prekypujúca plnost’ tak mnohonásobne navzájom previazaných hudobných obrazov, ktorými by inak musel prvý prednes ohromit’ a zmiast', vzbudí svojou plastickou hierarchiou pozornost’ aj u takých poslucháčov, ktorí nemali predtým možnost’ vypočut’ si skúšku tohto diela - ale tí, čo sú vyškolení vychutnávat' si hlbšie založenú koncertnú hudbu, sa predtým aspoň oboznámia s týmito letmými zbežnými riadkami.

Táto príprava je nevyhnutná už z hl'adiska poetického námetu, ktorý tu skladatel' nielen formálne zhudobňuje, akoby sa nakoniec každý text dal strčit do nejakej hudobnej zvieracej kazajky, ale vo všetkých smeroch ho dopĺña a prehlbuje mocnými prostriedkami dnešného hudobného umenia, a tak prebúdza k živej existencii takým spôsobom, že sa temné a letmé slovo básnika stáva pravdou, ktorá neodolatel'ne otriasa a rozochvieva našu dušu.

Azda len máloktorí si spomenú na túto báseň - a už málokto vôbec pochopí jej odvážnu a temnú reč. Kedže nie každý návštevník koncertu môže byṫ vybavený potrebnými literárnymi pomôckami, sme povinní predtým napomôct' potrebné pochopenie samotnej básne.

„Vznik tejto básne," hovorí Heinrich Viehoff, "spadá do jesene alebo do začiatku zimy roku 1771. O atmosfére, v ktorej vznikla, sa nám Goethe sám zmienil v diele Wahrheit und Dichtung. ${ }^{30}$ Po jeho návrate $z$ Univerzity $v$ Štrasburgu do rodného mesta mu Friederike Brionová ešte raz napísala a rozlúčila sa s ním spôsobom, ktorý mu roztrhol srdce. ,Bola to tá istá ruka,' píše Goethe, ,ten istý zmysel, ten istý pocit, ktoré sa ku mne, ktoré sa vo mne vyvinuli. Až teraz som pocítil stratu, ktorú utrpela, a nevidel som žiadnu možnost' ju nahradit', ba ani ju len zmiernit'. Bola stále pri mne, aj ked'som neustále cítil, že mi chýba a čo bolo najhoršie, nemohol som si odpustit' svoje vlastné neštastie. Gretchen mi vzali, Anette ma opustila, tu som bol po prvýkrát vinný; zranil som najkrajšie srdce v jeho hlbinách, a tak bolo obdobie temnej lútosti, pri nedostatku obvyklej potešujúcej lásky, nanajvýš trýznivé, ba až neznesitelné. Človek však chce 
höchst peinlich, ja unerträglich. Aber der Mensch will leben, daher nahm ich aufrichtigen Teil an andern, ich suchte ihre Verlegenheiten zu entwirren und was sich trennen wollte, zu verbinden, damit es ihnen nicht ergehen möchte, wie mir. Man pflegte mich daher den Vertrauten zu nennen, auch wegen meines Umherschweifens in der Gegend, den Wanderer. Dieser Beruhigung für mein Gemüt, die mir nur unter freiem Himmel, in Thälern, auf Höhen, in Gefilden und Wäldern zu Teil ward, kam die Lage von Frankfurt zu Statten, das zwischen Darmstadt und (Bad) Homburg mitten inne lag, zweien angenehmen Orten, die durch Verwandtschaft beider Höfe in gutem Verhältnis standen. Ich gewöhnte mich, auf der Strasse zu leben und wie ein Bote zwischen dem Gebirg und dem flachen Lande hin und her zu wandern. Oft ging ich allein oder in Gesellschaft durch meine Vaterstadt, als wenn sie mich nichts anginge, speiste in einem der grossen Gasthöfe der Fahrgasse und zog nach Tische meines Wegs weiter fort. Mehr als jemals war ich gegen offene Welt und freie Natur gerichtet. Unterwegs sang ich mir seltsame Hymnen und Dithyramben, wovon noch eine, unter dem Titel Wanderers Sturmlied, übrig ist. Ich sang diesen Halbunsinn leidenschaftlich vor mich hin, da mich ein schreckliches Wetter unterwegs traf, dem ich entgegen gehen musste.."'

Nach den obigen Bekenntnissen des Dichters muss es gleich auffallen, dass sich in den Gedichten nichts von jener quälenden Reue kundgibt, die er über sein Verhältnis zu Friederike Brion empfand. Es spricht sich vielmehr sogleich ein begeisterndes Gefühl des innewohnenden Genius aus, der ihn gegen alle Stürme des Lebens stählt. Denn dass wir den Sturm, gegen den er hier ankämpft, auch in höherem symbolischen Sinne zu fassen haben, unterliegt keinem Zweifel. Goethe sagt in seinen Bemerkungen zur "Harzreise im Winter": „Was von meinen Arbeiten durchaus und so auch von den kleinern Gedichten gilt, ist, dass sie alle, durch mehr oder minder bedeutende Gelegenheit, im unmittelbaren irgend eines Gegenstandes verfasst worden, deshalb sie sich nicht gleichen, darin jedoch übereinkommen, dass bei besondern äussern, oft gewöhnlichen Umständen, ein Allgemeines, Inneres, Höheres dem Dichter vorschwebte."

\author{
Wen du nicht verlässest, Genius, \\ Nicht der Regen, nicht der Sturm \\ Haucht ihm Schauer übers Herz. \\ Wen du nicht verlässest, Genius, \\ Wird dem Regengewölk, \\ Wird dem Schlossensturm \\ Entgegen singen, \\ Wie die Lerche, \\ Du da droben.
}

Das Allgemeine, das Höhere, das hier dem Dichter vorgeschwebt, liegt nahe genug: Wer den Genius sich fühlt, verliert auch unter den Stürmen des Schicksals die Ruhe, den Lebensmut nicht; er erhebt sich singend, wie die Lerche, über die niederen Regionen des Sturmes in den sonnigen, ruhigen Aether. Dann heisst es weiter im folgenden: der Genius hebt über den Schmutz des Lebens empor; wer von ihm erfüllt und getragen wird, der wandelt mit reinem Fuss („Blumenfüssen“) selbst durch den Schlamm gemeiner Verhältnisse:

Den du nicht verlässest, Genius, Wirst ihn heben übern Schlammpfad 
žit', preto som úprimne spolucítil s inými, usiloval som sa rozuzlit' ich t'ažkosti a spájat', čo sa chcelo odlúčit', aby nedopadli tak ako ja. Preto ma zvykli nazývat' dôverníkom a tiež tulákom pre moje potulky po okolí. Pre toto upokojenie mojej mysle, ktorého sa mi dostalo iba pod holým nebom, v údoliach, na výšinách, na pláňach a v lesoch, bola výhodná poloha Frankfurtu, ležiaceho uprostred medzi Darmstadtom a (Bad) Homburgom, dvomi príjemnými mestami, ktoré boli kvôli príbuzenstvu oboch dvorov ${ }^{31}$ $v$ dobrom vzájomnom vztahu. Zvykol som si žit na ulici a putovat ako posol sem a tam medzi pohorím a rovinou. Často som prechádzal sám alebo $v$ spoločnosti cez moje rodné mesto, akoby sa ma vôbec netýkalo, jedol som v jednom z vel'kých hostincov na Fahrgasse a po jedle som išiel d’alej svojou cestou. Viac ako kedykolvek predtým som bol zameraný na otvorený svet a volnú prírodu. Cestou som si spieval zvláštne hymny a oslavné piesne, z ktorých sa zachovala ešte jedna, pod názvom Wanderers Sturmlied. Zanietene som si pre seba pospevoval tento polonezmysel, ked'ma cestou zastihlo hrozné počasie, ktorému som musel ist'v ústrety.!"

Hned' po horeuvedených priznaniach básnika musí udriet’ do očí, že v básňach nedáva najavo nič z tej trýznivej lútosti, ktorú pocitoval vo svojom vztahu k Friederike Brionovej. Skôr je tu hned' vyjadrený oduševňujúci pocit jemu vlastného génia, ktorý ho zoceluje proti všetkým búrkam života. Pretože bez akýchkolvek pochybností máme chápat' búrku, proti ktorej tu bojuje, aj vo vyššom symbolickom význame. Goethe hovorí vo svojich komentároch k dielu Harzreise im Winter [Zimná cesta Harcom]: „O mojich prácach vo všeobecnosti, a teda aj o krátkych básňach platí, že všetky boli napísané pri viac alebo menej významnej príležitosti, priamo na nejakú tému, preto sa nepodobajú, zhodujú sa však v tom, že pri osobitých vonkajších, často bežných okolnostiach, sa v básnikových predstavách vznášalo čosi univerzálne, vnútorné, vy̌šsie."

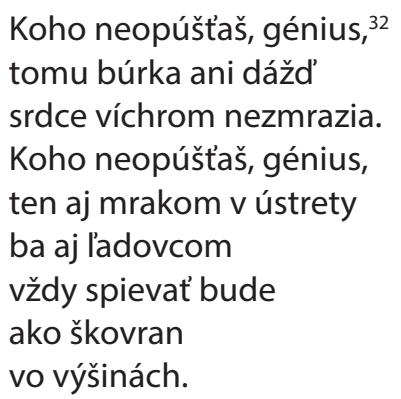

To univerzálne, to vyššie, čo sa tu vznáša v básnikových predstavách, leží na dosah: Kto cíti v sebe génia, nestratí ani v búrkach osudu pokoj a chut do života; vznesie sa spievajúc ako škovránok ponad nízke pásma búrky do slnečného, pokojného éteru. Ďalej sa píše nasledovne: génius sa pozdvihne nad špinu života; kto je ním naplnený a nesený, ten kráča čistou nohou („kvety v nohách“) dokonca aj bahnom prí̌̌erných pomerov:

Koho neopúštaš, génius, toho zdvihneš ponad kal 


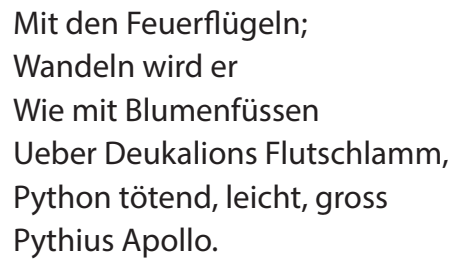

Die zwei letzten Verse geben einigen Anstoss. Wie kommt der Pythische Apollo plötzlich? Ich denke mir den Zusammenhang so: in den niedern Lebensverhältnissen, die eben durch „Deukalions Flutschlamm“ bezeichnet worden, hauset gemeines tückisches Gezücht, das dem Geniusbegabten drohend in den Weg tritt, wie der Drache Python dem Apoll, als er das Delphische Orakel in Besitz nehmen wollte. - Bis hieher schlossen sich die Gedanken an das augenblicklich Erlebte, das Gegenwärtige, an den Sturm, dem der Dichter entgegenkämpft, an den Schlammpfad, auf dem er rüstig daherschreitet. Nun führt ihm die Phantasie andere, doch verwandte Situationen vor:

\title{
Den du nicht verlässest, Genius, Wirst die wollnen Flügel unterspreiten, Wenn er auf dem Felsen schläft, Wirst mit Hüterfittichen ihn decken In des Haines Mitternacht.
}

Der Genius macht drückende Verhältnisse leicht und bietet Schutz in Gefahren. Dies alles sagt sehr bezeichnend, was die Poesie für Goethe war. Sie war ihm ein Läuterungsmittel für seine Seele, wenn diese von Leidenschaft getrübt wurde; sie gab ihm Ruhe um mit Goethes Worten in seiner "Zueignung", zu sprechen, wenn Schmerz und Lust rastlos durch die jungen Glieder getobt, kühlte am heissen Tage seine Stirn wie mit himmlischem Gefieder, besänftigte jede Lebenswelle und liess das Wehen banger Erdgefühle schweigen. Sie zog ihn oft von dem Abgrund gefährlicher Leidenschaften zurück, liess ihn auf schmalen, bedenklichen Pfaden dieses Lebens spielend, aber sicher wandeln.

\author{
Wen du nicht verlässest, Genius, \\ Wirst im Schneegestöber \\ Wärmumhüllen; \\ Nach der Wärme ziehn sich Musen \\ Nach der Wärme Charitinnen. \\ Umschwebt mich, ihr Musen, \\ Ihr Charitinnen! \\ Das ist Wasser, das ist Erde. \\ Und der Sohn des Wassers und der Erde, \\ Ueber den ich wandle \\ Göttergleich.
}

"Das ist Wasser" in V. 30 geht auf den herabströmenden Regen, den man sich stets fortdauernd denken muss. V. 31 "Sohn des Wassers und der Erde“ ist eine poetische Umschreibung für den „Schlamm“. Das Wasser für sich, „das Herz der Wasser“ und die Erde für sich, 


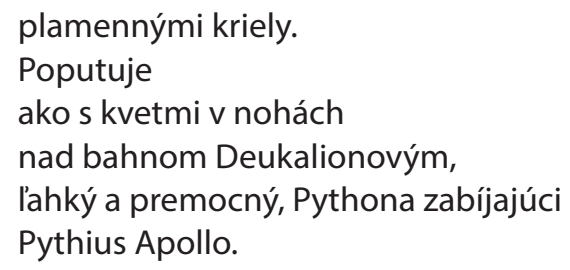

Dva posledné verše poskytujú viacero podnetov na rozmýšlanie: Kde sa tu tak náhle vzal ten pýtijský Apolón? Ja vidím súvislost' takto: v úbohých životných podmienkach, ktoré boli označené slovami „bahnom Deukalionovým”, prebýva podlá zákerná háved', ktorá sa géniom obdarenému hrozivo stavia do cesty, ako drak Pytón Apolónovi, ked' si chcel privlastnit’ delfskú veštiareň. - Až potial'to myšlienky nadväzovali na momentálne zažité, na prítomnost', na búrku, proti ktorej bojuje básnik, na kal, ponad ktorý si rezko vykračuje. Teraz mu fantázia predvádza iné, avšak podobné situácie:

\author{
Koho neopúštašs, génius, \\ tomu krídla z viny podostrieš, \\ ked'na skalisku spí, \\ perutou strážnou ho prikryješ \\ tam v hore polnočnej.
}

Génius ulahčuje sklučujúce pomery a poskytuje záštitu v nebezpečenstvách. Toto všetko vel'mi príznačne vypovedá, čo pre Goetheho znamenala poézia. Bola čistiacim prostriedkom pre jeho dušu, ked'ju kalila vášeň; dávala mu pokoj, použijúc Goetheho slová z jeho diela Zueignung [Venovanie], ked' bolest' a rozkoš neúnavne besneli mladými údmi, ochladzovala v horúci deň jeho čelo ako nebeskou perut’ou, utišovala každý životný nápor a umlčiavala vanutie sklučujúcich pocitov tiesne. Často ho stiahla spät' z priepasti nebezpečných náruživostí, nechala ho hravo, ale bezpečne kráčat’ po úzkych, pochybných chodníkoch tohto života.

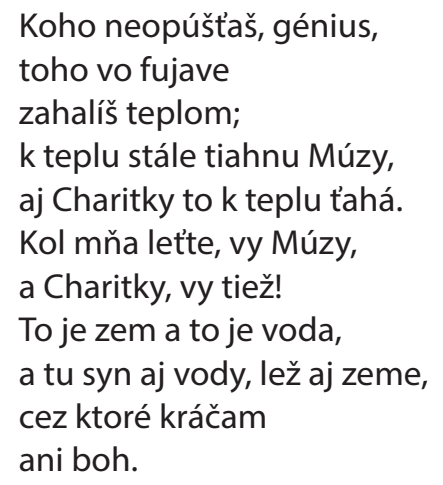

„To je voda“ v 30. verši sa týka stekajúceho dažda, ktorý si treba vždy predstavovat” ako trvalý. Ďalší, 31. verš „syn vody a zeme“ je poetickým opisom „bahna“. Voda sama osebe, „srdce vodstiev“ a zem sama osobe, „dreň tej zeme“, sú čisté; až zo spojenia 
"das Mark der Erde", sind rein; erst aus der Verbindung beider erzeugt sich das Unreine, als dessen Repräsentant vielleicht auch oben der Python zu denken ist. - Im folgenden wendet sich der Dichter wieder an die Musen und Charitinnen, die Spenderinnen alles Schönen und Anmutvollen. Wenn sie, die Reinen, ihn umschweben, so wandelt er rein, wie die Himmlischen, über den Schlammpfad. Es versteht sich, dass sich dies alles zunächst auf das wirklich Umgebende bezieht, dann aber auch ideeller zu fassen ist, wie Goethe zu einer Stelle in der Harzreise (V. 60-65) anmerkt, dass man sich bei Auslegung von Dichtern immer zwischen dem ideellen und dem Wirklichen zu halten habe:

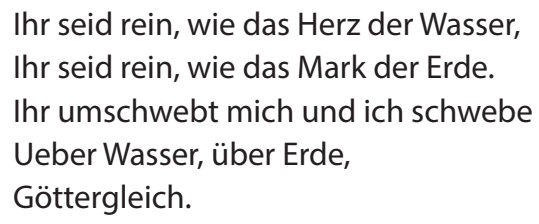

Den angeführten allgemeinen Teil des Gedichtes führt nun Richard Strauss in musikalischer Darstellung durch. Selbstverständlich kann hier keine fachgemässe Zergliederung von uns erwartet werden, und was wir darüber sagen, soll nur ein Wink sein, wie der Zuhörer aus den an ihn herantretenden Tonfluten sich das Richtige für den eigenen Kunstgenuss herausholen könnte.

In wuchtig ehernen Akkorden erbraust das Vorspiel: ein Sturmbild in grossen Zügen. Gleich aus dem ersten Akkord prasselt eine scharfzerbröckelte Tonfigur (eine für das ganze Werk höchst bezeichnend verwendete Septole) hervor, wie die heulende Windsbraut stöhnt eine Schar von Instrumenten auf, jähe Trompetenstösse zucken empor, grollend erheben sich die Bässe, immer gewaltiger türmen sich übereinander die erregten Wogen, endlich stürmt die im ersten Takte aufgetauchte (Septolen-) Figur von den Bässen durch alle Streichinstrumente hindurch bis zur ersten Geige herauf, - die Akkordmassen - gewaltsam in grell dissonierender Synkope geschoben - stauen sich, noch ein donnernder Paukenwirbel, und wie der Blitz funkeln die Geigen mit der Flöte in jähem Strahl empor: - der Sturm hat sich entladen.

Da, im selben Augenblick, ertönt das düster, aber markig erfundene Hauptthema des Sturmliedes „Wen du nicht verlässest, Genius“, mit dem sich anschliessenden und ebenso bemerkenswerten Motiv zu „nicht der Regen, nicht der Sturm", welches wie das vom Alt und vom 2. Bass einstimmig vorgebrachte Thema im Verlauf des ganzen Chorwerkes zu einer aussergewöhnlich sinn- und gestaltungsreichen Verwendung gelangt. Beim Ertönen der Singstimmen brechen die grossen Instrumentalmassen ab; von düsteren Harmonien der Holzbläser getragen, entfaltet sich nun der choristische Aufbau der ersten drei Zeilen des Liedes, das, vom kleinlichen Bilde des vom Sturm ereilten Poeten absehend, hier zum Sturmlied jenes ewig rastlosen Wanderers wird, der den Stürmen der Jahrtausende seinen kühnen Weg abringt: zum Sturmlied der Menschheit. Dieser tiefere Sinn musste es sein, der den Tondichter zu einer so grossartigen Darstellung allein zu begeistern vermochte. Wie die Völker Schar auf Schar den ewig feindlichen Mächten ihr würdigeres und inneres Dasein einst und jetzt noch abringen, in solchem Sinne tönt es zu uns herüber aus den kühn und trotzig aufeinanderfolgenden Chorstimmen, die - von den allmählig immer drohender heranwogenden Sturmmotiven des Orchesters von unten, von oben umklammert - in seltener Steigerung der vokalen Leistung bei den Schlussworten der dritten Zeile: „haucht ihm Schauer über's Herz" zu einer gewaltigen Gesamtwirkung sich vereinigen. Doch gleichzeitig hat schon auch das Orchester gleichsam alle seine Streitkräfte wieder herangezogen, es erfolgt ein neuer Ausbruch des Sturmes, und - als sollten die feindlichen Mächte diesmal das Feld 
oboch sa plodí nečisté, za predstavitela čoho možno považovat’ aj horeuvedeného Pytóna. - Následne sa básnik obracia znova na Múzy a Charitky, darkyne všetkého krásneho a pôvabného. Ked’ sa okolo neho vznášajú ony, čisté, tak putuje ponad kal čistý ako nebeštania. Rozumie sa samo sebou, že toto všetko sa najprv vztahuje na reálne okolité prostredie, treba to však potom chápat’ aj abstraktnejšie, ako Goethe poznamenáva k jednému miestu v diele Zimná cesta Harcom (verš 60 - 65), že pri výklade básnikov sa treba vždy držat’ medzi ideálnym a skutočným:

Ste čisté ako srdce vodstiev, ste čisté ako dreň tej zeme, letíte kol mňa a ja lietam ponad zem a ponad vodstvá ani boh.

Túto všeobecnú čast' básne teraz zhudobnil Richard Strauss. Samozrejme, nemožno tu od nás očakávat' odbornú analýzu, a to, čo uvedieme, má byt' len rada, ako by si poslucháč mohol vybrat’ z nadchádzajúcej záplavy tónov to správne pre svoj vlastný umelecký pôžitok.

V prudko neoblomných akordoch zaburáca predohra: obraz búrky vo vel'kých obrysoch. Hned'od prvého akordu udiera ostro rozdrobená hudobná figúra (septola nanajvýš charakteristická pre celé dielo) ako úpejúca nevesta vetra stoná zástup nástrojov, trúbky v prudkých nárazoch, dunivo sa dvíhajú basy, čoraz mocnejšie sa hromadia a prevalujú nadmuté vlny, nakoniec zaburáca (septolová) figúra, ktorá sa vynorila v prvom takte, od basov cez všetky sláčikové nástroje až nahor k prvým husliam, masy akordov - násilne posunuté v ostro disonantnej synkope - sa kopia, ešte hrmiaci vír bubnov a ako blesk zaiskria husle s flautou v náhlom lúči: búrka sa uvol'nila.

Tu, v tom istom momente, zaznie temne, ale výstižne vymyslená hlavná téma piesne v búrke „Koho neopúštaš, génius“, s nasledujúcim a rovnako pozoruhodným motívom k „ani búrka ani dážd”, ktorý ako téma jednohlasne prednášaná altom a 2. basom v priebehu celého zborového diela dospeje $k$ výnimočne dômyselnému a tvorivému použitiu. Pri zaznení spevných hlasov sa prerušia vel'ké inštrumentálne masy; nesená temnými harmóniami drevených dychových nástrojov sa teraz vyvíja zborová štruktúra prvých troch veršov piesne, ktorá - odhliadnuc od malicherného obrazu básnika zastihnutého búrkou - sa tu stáva piesňou v búrke onoho večne neúnavného tuláka, ktorý vybojúva svoju odvážnu cestu s búrkami tisícročí: piesňou v búrke ludstva. Určite to bol práve tento hlbší zmysel, ktorý dokázal skladatela nadchnút pre také vel'kolepé zobrazenie. Ako národy zástup za zástupom kedysi a ešte teraz vybojúvajú svoju dôstojnejšiu a vnútornú existenciu s večne nepriatel'skými mocnost’ami, v takomto zmysle znie smerom k nám z odvážne a vzdorovito za sebou nasledujúcich zborových hlasov, ktoré sa - zdola a zhora zovreté čoraz hrozivejšie sa približujúcimi búrkovými motívmi orchestra - zjednotia vo vzácnom vystupňovaní vokálneho výkonu pri záverečných slovách tretieho verša: „srdce víchrom nezmrazia“ k vel'kolepému celkovému účinku. Avšak súčasne aj orchester už znova zoradil takmer všetky svoje bojové sily, búrka následne prepukne nanovo, a - akoby mali nepriatel'ské sily tentoraz udržat' bojové pole - zbor zmĺkne pred 
behaupten - es verstummt der Chor vor den geharnischten Akkorden des Vorspiels, das sich wiederholen zu wollen scheint. Aber schon im dritten Takt erheben sich mit titanischer Kraft die Singstimmen unter ihrem Banner: ,Wen du nicht verlässest, Genius", und kaum erklingt das Wort "Genius", da beugt sich alles, der Sturm vertobt und ruhigen Mutes singt der Wanderer dem Regengewölk und Schlossensturm entgegen. Wie herrlich ist das hier gezeichnet! Ein kühn aufsteigendes Motiv (,Regengewölk“) tritt aus dem anfänglich sehr ruhigen Satz der Singstimmen hervor; es springt von einer Stimme zur anderen, durchzuckt sie alle wie ein elektrischer Strom, dass sie flugs gegen den Schlossensturm sich erheben und die Regionen des Gewölkes durchbrechend losgelöst vom Orchester ihr Lied hinabschmettern wie die Lerche oben. Nun greift der Tondichter zu den ersten drei Versen zurück und bringt so durch Wiederholung der ersten Darstellung die notwendige Einheit der Stimmung in den Abschluss der ersten Strophe.

In mächtig ergreifender Einstimmigkeit verhallt der Chor. Ohnmächtig grollt nun endlich auch der Sturm ab. Über den leise flutenden Akkorden der Streichinstrumente, die hier die Rolle des "Schlammpfades" und "Flutschlammes" übernehmen, erklingt eine schmelzende Melodie der Holzblasinstrumente, dieselbe, die später der Tondichter dazu verwendete um den Wanderer „wie mit Blumenfüssen“ wandeln zu lassen. Der Chor beginnt nun die zweite Strophe, deren musikalische Darstellung ein non plus ultra moderner Kompositionskunst genannt werden muss. Nachdem der Tondichter jedes Bild dieser Strophe in getreuer musikalischer Fassung uns lebendig vor die Seele geführt hat, entrollt er, angefangen von den Worten:„Python tötend, leicht, gross", ein gewaltiges Gemälde, in welchem sich der in riesige Dimensionen erweiterte Inhalt der Strophe abspielt. Die Menschheit ist es, die über alle die gewaltigen Hindernisse hinweg so hohen Fluges sich erhebt, die Menschheit, die den Drachen ihrer Unfreiheit tötet, sie ist es, die aus diesem ewigen Ringkampf immer wieder leicht und gross ersteht und triumphierend wie ein Gott über dem ihr zugefallenen kleinen und dennoch so grossen Stück Welt waltet! Um dieser Darstellung mit einigem Verständnis folgen zu können, wolle der Zuhörer aufmerksam folgende drei Motive im Gedächtnisse behalten: 1. dasjenige, welches in reizend melodischer Weise zu den Worten:,,wandeln wird er wie auf Blumenfüssen“, erklingt; 2. jenes, das wie ein siegreicher Held in wuchtig markierten Tönen die Stelle: „Python tötend, leicht, gross“ wiedergibt und später wohl auch im Chor, aber hauptsächlich im Orchester in blanker Messingrüstung scharf hervortritt, und 3. das Motiv zu „Pythius Apollo", das aus einer triumphierend sich aufschwingenden Triole besteht. Dieser Motive bedient sich unser Tondichter zur Herstellung seines genial entworfenen Gemäldes in so kunstvoller Weise, dass hier dem Zuhörer bei der ersten Wiedergabe des Werkes keine verständnisvolle Auffassung zugemutet werden kann. Aber der grosse Zug, der diesem im Tonbilde so lebendig sich abspiegelnden Ringen der Menschheit nach idealem Gut, nach Freiheit und nach dem ihr über der Materie gebührenden „Göttlichwerden“ innewohnt, verleiht äusserlich dieser zweiten Strophe des Chorwerkes ein so rauschendes Gepräge, dass auch schon dieser äusserliche Genuss den Zuhörer vollends hinreissen kann, wenn er wenigstens die hier entwickelten Gedanken im Sinne behält. Am Schlusse erklingt in zweimaliger Steigerung der gloriose Ausruf des Chors: „Pythius Apollo“, jedesmal zuerst ohne das Instrumentale, dann aber vom Orchester in triumphierendem Pomp zur strahlenden Höhe hinaufbegleitet.

Nun ist die triumphale Musik verrauscht. Auf immer ruhiger werdenden Akkorden haften sich die zarteren Blasinstrumente fest, um - während die Violinen und Bratschen das Motiv: „wandeln wird er wie mit Blumenfüssen“ in immer hellere Regionen empor tragen - vollends zu verhallen. Sanft steigt das Motiv nieder und gibt den traumhaft aufdämmernden Bildern Raum, die gleichsam nur die Phantasie aus dem vergangenen Sturm milde und verklärend vor die Seele des ruhenden Wanderers zurückrufen. Eine wunderbare Ruhe - wie auf ho- 
obrnenými akordmi predohry, ktorá sa zdanlivo navracia. Avšak už v tret’om takte sa pod svojou zástavou s nadludskou silou zdvihnú spevné hlasy: „Koho neopúšt’aš, génius", a sotva zaznie slovo „génius“, všetko sa skloní, besnenie búrky odznie a tulák spieva s pokojnou mysl'ou dažd’ovému mraku a ladovcovej búrke v ústrety. Ako nádherne je to tu znázornené! Odvážne nastupujúci motív („dažd’ový mrak“) vystupuje zo spočiatku vel'mi pokojného súboru spevných hlasov; skáče z jedného hlasu do druhého, prejde nimi všetkými ako elektrický prúd tak, že sa letom dvíhajú proti ladovcovej búrke a preraziac oblasti mračna zahlaholia svoju pieseň oddelene od orchestra ako škovránok na nebi. Teraz sa skladatel' vráti k prvým trom veršom a prenesie tak opakovaním prvého stvárnenia potrebnú jednotnú náladu do záveru prvej strofy.

Zbor doznieva v nesmierne uchvacujúcej jednohlasnosti. Nakoniec omračujúco dorachotí aj búrka. Ponad ticho prúdiace akordy sláčikových nástrojov, ktoré tu preberajú úlohu „kalu“ a „bahna potopy“, zaznie dojímavá melódia drevených dychových nástrojov, tá istá, ktorú skladatel' neskôr využil, aby nechal tuláka kráčat’ „ako s kvetmi v nohách“. Zbor teraz začína druhú strofu, ktorej zhudobnenie treba nazvat' non plus ultra moderného kompozičného umenia. Po tom, čo nám skladatel' živo predviedol každý obraz tejto strofy vo vernom hudobnom znení, rozvinie počnúc slovami „l'ahký a premocný, Pythona zabíjajúci“ majestátnu mal'bu, na ktorej sa odohráva obsah strofy rozšírený do obrovských rozmerov. Je to ludstvo, ktoré sa dvíha krížom cez všetky tie ohromné prekážky takým vysokým letom, ludstvo, ktoré zabíja draka svojej neslobody, ono je to, ktoré z tohto večného zápasu vždy znova l'ahko a vel'ké povstáva a triumfujúc ako boh spravuje malý, a predsa taký vel'ký kus sveta, ktorý mu pripadol! Aby mohol poslucháč sledovat’ toto stvárnenie s istým porozumením, nech si pozorne uchová v pamäti nasledujúce tri motívy: 1.) ten, ktorý zaznie pôvabne melodickým spôsobom na slová: „poputuje ako s kvetmi v nohách“; 2.) ten, ktorý ako vítazný hrdina svižne označenými tónmi zobrazuje miesto "lahký a premocný, Pythona zabíjajúci“ a neskôr ostro vystúpi v lesklej mosadznej výzbroji zaiste aj v zbore, ale najmä v orchestri, a 3.) motív k „pýtijský Apolón“, ktorý pozostáva z triumfálne sa povznášajúcej trioly. Tieto motívy používa náš skladatel' na vytvorenie svojej geniálne načrtnutej mal'by takým umeleckým spôsobom, že pri prvej reprodukcii diela nemožno očakávat’ od poslucháča vnímanie s porozumením. Avšak ten mohutný t’ah, napĺňajúci tento hudobný obraz, ktorý živo zrkadlí zápas ludstva o ideálne dobro, o slobodu a o jemu skrz matériu prináležiace „zbožštenie“, dodáva zjavne tejto druhej strofe zborovej skladby taký opojný charakter, že už aj tento vonkajší pôžitok môže poslucháča úplne nadchnút', ak si zachová v mysli aspoň tu rozvinuté myšlienky. Na záver zaznie dvakrát vystupňované pôsobivé prevolanie zboru "Pythius Apollo", zakaždým najskôr bez nástrojov, potom však orchestrom sprevádzané v triumfujúcej nádhere k žiarivej výšine.

Triumfálna hudba už odznela. Jemnejšie dychové nástroje sa upínajú na čoraz pokojnejšie akordy, aby - kým husle a violy vynášajú motív: „Poputuje ako s kvetmi v nohách" do čoraz svetlejších oblastí - úplne odzneli. Motív l'ahko zostupuje a dáva priestor zasnene svitajúcim obrazom, ktoré akoby znova jemne a zjasňujúco vyvolávali iba fantáziu z uplynulej búrky v duši oddychujúceho tuláka. Neobyčajný pokoj - ako na vysokom skalnatom chrbte vzdialených vel'hôr, tlmenejšie svetlo - ako na sklonku dňa - sa vylieva sa ponad scénu: tulák spí, a iba v znejúcom hlavnom motíve („Koho 
hem Felsrücken des fernen Hochgebirges, ein sanfteres Licht - wie beim Neigen des Tages - ergiesst sich über die Szene: der Wanderer schläft, und nur im erklingenden Hauptmotiv ("Wen du nicht verlässest, Genius") erscheint das Bild des Genius als treuen Hüters auf dem Felsen und in des Haines Mitternacht. Der aus den beiden Sopranen, Alt und Tenor zusammengestellte Chor gibt diesem Idyll einen treffenden Ausdruck und wird darin wunderbar vom Geigenchor unterstützt, der die Singstimmen mit zart angehauchten Figuren als Bild des seine Flügel unterspreitenden Genius umfächelt. Im Augenblicke, wie das Bild des schlafenden Wanderers vorüber ist, senkt sich ein tiefes Dunkel über die Farben, - die helleren Stimmen verstummen sämtlich: wie durch eine zauberhafte Verwandlung versetzt uns die Komposition in des Haines Mitternacht, und gar seltsam berührt es, wenn der lieblichste Klang des Chores nun von einstimmig geführten Bass-Stimmen, die aus dunkler Tiefe emportauchen, abgelöst wird. Hat der Komponist die ersten Strophen in Granit gemeisselt, so ist diese dritte eine reizende Filigranarbeit, die sich nicht nur durch magisches Colorit und Schärfe des Ausdrucks auszeichnet, sondern auch namentlich durch den ihr innewohnenden rührenden und geheimnisvoll angehauchten Zug ausserordentlich fesselt.

Doch schon heben die oberen vier Singstimmen und ihnen gleich nach die Bassstimmen die vierte Strophe an: „Wen du nicht verlässest, Genius“: - ein paar aufwirbelnde Geigenfiguren reissen mit einem Ruck unsere Vorstellung aus des Haines Mitternacht, - Dichter und Komponist versetzen uns in stürmisches Schneegestöber, verwirrend und Atem hemmend, dass wir endlich ganz froh das Erscheinen der Musen und Charitinnen begrüssen. Schier erdrückend schiebt der Tondichter hier die Singstimmen in und durcheinander und lässt sie von seiner genial erdachten und so mannigfach symbolisch umdeutenden Septole, die sich hier zu einer Flockenfigur krystallisiert, scharf umstöbern.

Das Gestöber tobt aus. Die Singstimmen leiten wie von einem Alp befreit a capella mit den Textesworten „nach der Wärme ziehn sich Musen“ zur nächsten über.

Ein ritardierender zarter Übergang der Hörner, Trompeten und Pauken bringt uns unter Anführung der Altstimmen („umschwebt mich, ihr Musen, ihr Charitinnen“) in die warmpulsierende Nähe der Musen und zu den holden Spenderinnen der Anmut. In seligstem Wettstreit rufen die Singstimmen nacheinander "umschwebt mich“, dann lullt ein süsser Zauber dies freudig, aber sanft wogende Bild in Ruhe und Frieden ein. Nun mag das schwebende, dräuende Regengewölk seine Wasser ergiessen, - der Wanderer ist durch die Berührung mit Musen und Grazien selbst göttlich geworden und wandelt über allem Niedrigen göttergleich! In herrlichem Tongepränge führt der Komponist diese Strophe zum Abschluss, lässt die Gedanken derselben noch in einem festlichen Nachspiel des Orchesters ausklingen und wendet sich dann in einem fast zur Andacht stimmenden Übergang, in welchem die Schlussakkorde allmählich sozusagen bis zur heiligen Ruhe eines Orgelklanges sich abstufen, zur letzten Strophe des Sturmliedes.

Wie ein Choral sanft und leidenschaftslos dringt zu uns der Zusammenklang der Stimmen, wenn sie mit den Worten „ihr seid rein, wie das Herz der Wasser" einsetzen; aber die Nähe der Musen und Charitinnen bringt sofort eine zart rege Bewegung hinein, sobald die musikalische Darstellung zu den Worten „ihr umschwebt mich“ gelangt. Das ist nun hier eine gar feine Zeichnung. Das begleitende Spiel der Flöten, Klarinetten und Hörner hebt und senkt sich abwechselnd in zierlicher Art wie Schmetterlingsfügel, während das musikalische Motiv zu „ihr umschwebt mich" sanft sechs Chorstimmen mehrfach durchfliegt. Dies Motiv ist eine auffliegende Triole, genau dieselbe, die uns den göttlich sich erhebenden Pythius Apollo musikalisch wiedergab, doch hier weich und zart ins Weibliche übersetzt und somit gleichsam dies Umschweben der Musen und Charitinnen mit "Göttlichwerden“ identifizierend. Mit dem Einsatz der Worte „und 
neopúštaš, génius") sa objaví obraz génia ako verného ochrancu na skale a v polnočnej hore. Zbor zložený z oboch sopránov, altu a tenoru dáva tejto idyle výstižný výraz a nádherne ho v tom podporuje zbor huslí, ktorý ovieva spevné hlasy vzletnými figúrami ako obraz génia roztahujúceho svoje krídla. $V$ momente, ako zmizne obraz spiaceho tuláka, spustí sa ponad farby hlboké temno, všetky svetlejšie hlasy zmĺknu: ako cez kúzelnú premenu nás kompozícia prenesie do polnočnej hory a vel'mi zvláštne sa nás dotkne, ked' lúbezný zvuk zboru teraz nahradí unisono basových hlasov, ktoré sa vynoria z tmavej híbky. Ak skladatel' vytesal prvé strofy do žuly, tak táto tretia je pôvabnou filigránskou prácou, ktorá sa nielen vyznačuje magickým koloritom a ostrým výrazom, ale aj neobyčajne upúta menovite svojou v nej obsiahnutou dojemnou a tajuplne sfarbenou črtou.

Vtedy začínajú štyri vrchné spevné hlasy a hned' po nich basové hlasy štvrtú strofu: „Koho neopúštaš, génius": pár vírivých huslových figúr vytrhne šklbnutím našu predstavu z polnočnej hory, básnik a skladatel' nás premiestňujú do prudkej mätúcej a dych berúcej fujavy, takže nakoniec velmi radi privítame zjavenie Múz a Charitiek. Takmer taživo tu skladatel' prepletá spevné hlasy cez seba navzájom a necháva ich ostro sa rozvírit vo svojej geniálne vymyslenej rozmanito symbolicky viacznačnej septole, ktorá sa tu kryštalizuje do podoby vločky.

Fujavica sa vybúri. Spevné hlasy a cappella akoby oslobodené od nočnej mory prechádzajú d’alej so slovami textu „k teplu stále tiahnu Múzy“.

Spomalujúci nežný prechod lesných rohov, trúbok a bubnov nás prenáša pod vedením altových hlasov („kol mňa lette, vy Múzy, a vy, Charitky, tiež!") do teplo pulzujúcej blízkosti Múz a k spanilým darkyniam pôvabu. V najblaženejšom súperení volajú spevné hlasy jeden za druhým „kol mňa lette“, potom sladké kúzlo ticho a pokojne uspáva tento radostne, ale jemne sa kolísajúci obraz. Teraz môže vznášajúci sa, hroziaci búrkový mrak vyliat’ svoje vody, tulák sa dotykom s Múzami a Gráciami sám stal božským a kráča ani boh nad všetkým nízkym! V nádhernej pompe tónov ukončuje skladatel' túto strofu, necháva jej myšlienky dozniet' ešte v slávnostnej dohre orchestra a potom sa obracia až v akomsi nábožnom prechode, $v$ ktorom sa záverečné akordy postupne rozpúštajú takpovediac až k posvätnému pokoju zvuku organa, $\mathrm{k}$ poslednej strofe Pútnikovej piesne v búrke.

Ako chorál jemne a bez vášne $k$ nám preniká súzvuk hlasov, ked’ nastupujú so slovami „ste čisté ako srdce vodstiev“; ale blízkost” Múz a Charitiek okamžite vnáša nežný rušný pohyb, akonáhle zhudobnenie dospeje k slovám "kol mňa lette“. Toto je vel'mi pekné zobrazenie. Sprievodná hra fláut, klarinetov a lesných rohov sa striedavo dvíha a klesá pôvabne ako motýlie krídla, zatialčo hudobný motív ku „kol mňa lette“ viackrát jemne preletí šiestimi zborovými hlasmi. Tento motív je vzlietajúca triola, presne tá, ktorá nám hudobne zobrazila božsky sa dvíhajúceho pýtijského Apolóna, tu však mäkko a nežne premietnutá do ženského princípu, a teda akoby identifikujúca toto vznášanie sa Múz a Charitiek so "stávaním sa božským, zbožštením“. S nástupom slov "a ja lietam ponad zem a ponad vodstvá" sa teraz začína okázalý záver zborového diela. Zatial' čo sa spevné hlasy blížia v mohutne stúpajúcej gradácii k žiarivej záverečnej fáze „ani boh“, kompozícia prináša skoro všetky hudobné motívy použité v priebehu diela $v$ orchestri v rovnako vel'kolepom stupňovaní, a nahor sa vznáša more záplav tónov peniacich rozkošou, kým slnečný radostný let nedosiahne svoj vrchol vo zvolaní „ani boh“ triumfálne obsypanom ligotavými fanfárami lesných 
ich schwebe über Wasser, über Erde" beginnt nun der glänzende Abschluss des Chorwerkes. Während die Singstimmen in einer gewaltig aufsteigenden Klimax der glanzvollen Schlussphase "göttergleich" zustreben, trägt die Komposition fast alle im Verlauf des Werkes verwendeten musikalischen Motive im Orchester in ebenfalls grossartiger Steigerung hinzu, und himmelan schwebt ein Meer von wonneschäumenden Tonfluten, bis der sonnige Freudenflug in dem triumphal von schimmernden Hörner- und Trompetenfanfaren umrauschten Ruf:„,göttergleich“ seinen Höhepunkt erreicht. Dem Schluss zu stuft sich dieser Pomp der Töne wieder allmählich ab und in olympischer Ruhe, sich selbst genügend, singt noch der Chor vor der Schlusswendung ohne Orchester sein verklärtes "göttergleich“ zweimal und verhällt dann pianissimo im Einklang. Wie eine Glorie strahlt nun ein zarter Schimmer der hellsten Orchesterklänge auf diesen Aushauch des Chores nieder, und, wie auf Blumenfüssen vom süssesten Klang der Violinen emporgetragen, entschwebt des Wanderers Bild unter den Grüssen des Genius zu himmlischen Sphären.

Möge diese kurze Vorbesprechung dazu dienen, einer herrlichen Schöpfung der Neuzeit wenigstens theoretisch jene Aufnahme vorzubereiten, die mit dem Stoff und Sinn der zu erwartenden Darstellung bereits vertraut, gewiss nicht mehr ohne tieferen Eindruck und Nachhall vor sich gehen kann.

J. L. Bella

4

München, den 16. Dec. 1888

Mein lieber Herr Bella!

In freundlichster Weise wurde ich gestern durch Ihre Vorbesprechung meines Sturmliedes überrascht; dieselbe ist ja wundervoll, die schönste Kritik, die ich noch je über eines meiner Werke gelesen habe. Aus den beiden Ihnen von mir gesandten Besprechungen des Sturmliedes ersehen Sie ja die dilettantische und oberflächliche Art und Weise, in der sich die meisten Beurteiler mit einem doch immerhin so complicierten Werke, wie das Sturmlied, abzufinden pflegen. Dass Sie, mein lieber Herr Bella, sich die Mühe genommen haben, in so liebevoller Würdigung meines Werkes Ihr Publikum auf dasselbe vorzubereiten, dafür bin ich Ihnen zu grossem Dank verpflichtet, abgesehen noch von der persönlichen grössten Freunde, die mir die so ausserordentlich schmeichelhafte Beurteilung meines Werkes bereitet hat. Also vielen, vielen Dank!

H. Dorn schrieb einmal über das Sturmlied, er begriffe nicht, wie man dasselbe, das Goethe selbst als „Halbunsinn“ bezeichnet habe, componieren könne. Ha!

Hoffentlich ist die Aufführung zu Ihrer Zufriedenheit verlaufen!

Bitte, schicken Sie mir bald Ihre Compositionen, auf die mich sehr freue.

Beiliegendes Bild (soeben erschienen) bittet Sie freundlichst aufnehmen zu wollen $\mathrm{Ihr}$

Sie herzlich grüssender, hochverehrender

Richard Strauss 
rohov a trúbok. Ku koncu sa táto nádhera tónov znova pomaly odstupňuje a v božskom pokoji, sám si vystačiac, zaspieva ešte zbor bez orchestra pred záverečným zvratom dvakrát svoje zjasnené „ani boh“ a potom doznieva pianissimo v súzvuku. Ako gloriola teraz zažiari nežný záblesk najjasnejších zvukov orchestra na tento výdych zboru, a, ako s kvetmi v nohách nesený nahor najsladším zvukom huslí, vznáša sa obraz tuláka za pozdravov génia k nebeským sféram.

Kiež by táto krátka predbežná úvaha poslúžila na to, aby pripravila vel'kolepému dielu novoveku aspoň teoreticky také prijatie, ktoré už oboznámením s námetom a zmyslom očakávaného predvedenia nepochybne zanechá hlboký dojem a ohlas.

J. L. Bella

4 List Richarda Straussa Jánovi Levoslavovi Bellovi

Mníchov, 16. decembra 1888

Môj milý pán Bella!

Včera som bol tým najprívetivejším spôsobom prekvapený Vaším predbežným posudkom na moje dielo Sturmlied; je nádherný, je tou najkrajšou kritikou mojich diel, akú som kedy čítal. Ved'v oboch recenziách diela Sturmlied, ktoré som Vám zaslal, vidíte diletantský a povrchný spôsob, akým sa väčšina recenzentov zvykne vyrovnat' s takým predsa len komplikovaným dielom, akým je Sturmlied. Za to, že ste si, môj milý pán Bella, dali tú námahu, takým láskavým ocenením môjho diela pripravit naň Vaše publikum, som Vám zaviazaný k velkej vd’ake, odhliadnuc od osobnej najväčšej radosti, ktorú mi pripravil taký výnimočne lichotivý posudok môjho diela. Teda velká, vel'ká vd'aka!

H. Dorn raz napísal o diele Sturmlied, že nechápe, ako sa dá zhudobnit čosi, čo sám Goethe označil ako „polovičný nezmysel“. Ha!

Dúfam, že predvedenie prebehlo $\mathrm{k}$ Vašej spokojnosti!

Prosím, pošlite mi čím skôr Vaše skladby, na ktoré sa vel'mi teším.

Priložený obrázok (práve vyšiel) Vás prosí priatel'sky prijat’

Váš

So srdečným pozdravom a hlbokou úctou

Richard Strauss 
Mein sehr verehrter, lieber Herr Bella!

In Eile also nochmals herzlichsten Dank für die jedenfalls sehr gelungene Ausführung des Sturmliedes; ich bedauere nur, es nicht selbst hören gekonnt zu haben. Bitte: schicken Sie mir bald Ihre versprochenen Compositionen!

Mit besten Grüssen Ihr in aufrichtigster Verehrung stets dankbar ergebenster

Richard Strauss

6

Weimar, 25. Oktober 89.

Mein lieber Herr College!

Haben Sie herzlichsten Dank für Ihren liebenswürdigen Brief und Ihr mir darin bewiesenes großes Vertrauen, für welches ich Ihnen von ganzem Herzen dankbar bin. Seien Sie versichert, dass Sie dasselbe keinem Unwürdigen geschenkt haben und dass ich stets bestrebt sein werde, mich desselben voll und ganz würdig zu erweisen! Bitte, senden Sie mir doch so bald als möglich Ihre neuen Werke, von ihrer symphonischen Dichtung womöglich Partitur und Orchesterstimmen. Die 4 Concerte, die ich hier zu dirigieren habe, finden am 28. Oktober, 11. und 25. November und 9. December statt, und wenn es irgend geht, nehme ich /hr Werk noch in die Programme derselben auf. Ihre Klaviersonate (verzeihen Sie, dass ich dieselbe so lange behalten habe) sende ich Ihnen dieser Tage zurück. Wäre es nicht möglich, dieselbe dahin etwas umzuarbeiten, dass der Klaviersatz (rein technisch) etwas bequemer spielbar würde; so vortrefflich Ihr Werk in der Empfindung ist, so ist doch, wie ich glaube, der etwas unbequeme Klaviersatz Schuld, dass kein Verleger (abgesehen von der Abneigung dieser Ehrenmänner gegen Klaviersonaten) dieselben gerne drucken und kein Klavierspieler von Fach, die ja den echten Klavierstyl bekanntlich in Pacht haben, dieselbe gerne studieren wird. Haben Sie keinen Pianisten, der die Chopin- Liszt'sche Klaviertechnik, die allen ja heute gut in den Fingern liegt und von der sie nicht gerne abgehen, genau kennt, in Hermannstadt, den Sie darüber zu Rate ziehen könnten? Bevor ich die Sonate Ihnen sende, werde ich sie hier noch Bernhard Stavenhagen vorspielen, vielleicht gelingt es mir, diesen für lhr vortreffliches Werk zu interessieren. Sie sind alle so bockbeinig und begriffstützig, diese Pianisten von heutzutage!

Bitte schicken Sie mir also Ihre neuen Sachen und seien Sie versichert, dass ich, was ich kann, für dieselben thun werde.

Nochmals herzlichen Dank für Ihren lieben Brief und die besten Grüsse Ihres in grosser Verehrung dankbar ergebensten

Richard Strauss 
5 List Richarda Straussa Jánovi Levoslavovi Bellovi

Mníchov, 21. decembra 1888

Môj velavážený, milý pán Bella!

Narýchlo teda ešte raz čo najsrdečnejšia vd'aka za Vaše rozhodne vel'mi vydarené predvedenie diela Sturmlied; iba lutujem, že som si ho nemohol osobne vypočut'. Prosím: pošlite mi čoskoro Vaše prislúbené kompozície!

So srdečným pozdravom Váš s najúprimnejšou úctou vždy vd’ačne najoddanejší

Richard Strauss

6 List Richarda Straussa Jánovi Levoslavovi Bellovi

Weimar, 25. októbra 1889

Môj milý pán kolega!

Najsrdečnejšia vd’aka za Váš láskavý list a Vašu vel'kú dôveru, ktorú ste mi v ňom preukázali a za ktorú som Vám z celého srdca vd’ačný. Bud'te uistený, že ste túto nedarovali niekomu nehodnému a budem sa neustále snažit’ preukázat', že som jej plne a celkom hodný! Prosím, pošlite mi predsa čo možno najskôr Vaše nové diela, z Vašej symfonickej básne pokial' možno partitúru a orchestrálne hlasy. Štyri koncerty, ktoré tu mám dirigovat', sa budú konat' 28. októbra, 11. a 25. novembra a 9. decembra, a ak to bude nejakým spôsobom možné, ešte zaradím do ich programov aj Vaše dielo. Vašu Klavírnu sonátu (prepáčte, že som si ju tak dlho nechal) Vám v týchto dňoch pošlem naspät'. Nebolo by možné ju dovtedy trocha prepracovat', aby bola klavírna sadzba (čisto technicky) hratel'ná o čosi pohodlnejšie; ako skvelé je Vaše dielo na pocit, tak si myslím, že predsa len trocha nepohodlná klavírna sadzba je na vine, že ju žiadny vydavatel' (odhliadnuc od averzie týchto poctivcov ku klavírnym sonátam) nevydá rád a žiadny klavirista odborník - ktorí predsa, ako je známe, majú pravý klavírny štýl v árende - rád nenaštuduje. Nemáte v Sibini klaviristu, detailne poznajúceho chopinovsko-lisztovskú klavírnu techniku, ktorú majú predsa dnes všetci dobre nacvičenú a neradi ju opúštajú, s ktorým by ste sa o tom mohli poradit’? Než Vám Sonátu zašlem, prehrám ju tu ešte Bernhardovi Stavenhagenovi, možno sa mi podarí zaujat’ ho Vaším skvelým dielom. Títo dnešní klaviristi sú všetci takí tvrdohlaví a nechápaví!

Prosím pošlite mi teda Vaše nové veci a bud'te si istý, že pre ne urobím všetko, čo budem môct'.

Ešte raz srdečná vd’aka za Váš milý list a najsrdečnejšie pozdravy od Vášho vo vel'kej úcte vd’ačne najoddanejšieho

Richarda Straussa 
Sehr verehrter, lieber Herr Bella!

Sie werden mir wohl sehr zürnen, dass ich so lange nichts von mir hören liess; die erste Zeit nach Empfang Ihres interessanten Werkes fehlte es mir an Musse, ihnen darüber zu berichten, denn ich hatte in meiner neuen Stellung anfangs rasend zu thun und bitte Sie herzlichst, mir meine Unhöflichkeit freundlichst zu verzeihen; da ich keine Gelegenheit hatte, in den 4 Abonnementsconcerten, die ich Anfang der Saison zu dirigieren hatte, Ihr Werk mehr zur Aufführung zu bringen, habe ich dasselbe beim „allgemeinen deutschen Tonkünstlerverein", dessen Vorsitzender mein Intendant Baron von Bronsart ist, behufs Aufführung bei der diesjährigen Tonkünstlerversammlung in Eisenach (Mitte Juni), die ich zum grössten Teile in ihren Concerten leite, eingereiht, warte aber bei dem langwierigen Weg, den ein Werk bei der gesammten musikalischen Commission des Vereines zu durchschreiten hat, bis heute auf einen Bescheid. Sobald ich denselben habe, werde ich Ihnen denselben zukommen lassen. -

Was Ihr Werk betrifft (verzeihen Sie, wenn so ein schriftliches Urteil nicht so deutlich ausfallen sollte, als man es im mündlichen directen Verkehr, formulieren kann), so hat mich dasselbe durch seine Eigenart, d. h. die durchaus originelle Sprache, die Sie sprechen, in hohem Grad interessiert, um so mehr, als mir die tragische, dichterische Grundidee sehr sympatisch ist. Ob dieselbe in ihrer musikalischen Ausführung eine so deutliche Gestalt gewonnen hat, daß sie bei der Aufführung auf unmittelbares Verständnis rechnen darf, wage ich allerdings zu bezweifeln. Wenn ich einerseits den Contrast der grossen Gegensätze des Schicksals und des von ihm schliesslich niedergezwungenen Ideals nicht prägnant genug finde, so stehe ich den thematischen Gruppen, in die Sie ihr "Schicksal“ gelegt haben, und die zum Teil so merkwürdig kurzatmig und zersplittert sind, dass sie nicht einmal in einem langen, fruchtbaren Aufbau zu einer großen Katastrophe steigern, die man schliesslich, da ein detailliertes Programm, auf das man hier angewiesen ist, nicht beigegeben ist, - wohl erwartet, - aufrichtig gesagt, ziemlich verdutzt gegenüber und weiß nicht recht, was ich mit ihnen anfangen soll. Die Vertreter der hiesigen Musik teilen sich doch in zwei Gruppen, die einen, denen Musik „Ausdruck" ist und die sie als eine ebenso präcise Sprache behandeln wie die Wortsprache, aber allerdings für Dinge, deren Ausdruck eben der letzteren versagt ist. Die anderen, denen die Musik "tönende Form" ist, d. h. sie legen dem zu componierenden Werke (die Form, d. h. nicht mehr Form, sondern Formel der Classiker ruhig gedankenlos beibehaltend), irgend eine allgemeine Grundstimmung unter und entwickeln diese entsprungenen Themen nach einer ganz äusserlichen, musikalischen Logik, für die mir heute, da ich nur mehr eine dichterische Logik anerkenne, schon jedes Verständnis fehlt.

Programmusik: - eigentliche Musik!

Absolute Musik: - ihre Verfertigung mit Hilfe einer gewissen Routine und Handwerkstechnik jedem nur einigermassen musikalischen Menschen möglich.

Erstere: - wahre Kunst!

Zweite: - Kunstfertigkeit!

Nun hat ja merkwürdigerweise unsere heutige Musik ihren Ausgangspunkt von No. II genommen und ist erst durch Wagner und Liszt vollbewusst ihrer wahren Bestimmung zugeführt worden. 
Viedeň, 3. marca 1890

Velavážený, milý pán Bella!

Asi sa na mňa budete vel'mi hnevat', že som tak dlho nedal o sebe nič vediet'. Hned' po prijatí Vášho zaujímavého diela som nemal čas Vám o tom referovat', pretože som v mojom novom postavení mal spočiatku šialene vel’a práce a prosím Vás srdečne, aby ste mi láskavo prepáčili moju nezdvorilost'. Ked’že som už nemal príležitost' uviest’ Vaše dielo počas štyroch abonentných koncertov, ktoré som mal dirigovat' začiatkom sezóny, zaradil som ho na program „Všeobecného nemeckého spolku hudobných umelcov", ktorého predsedom je môj intendant Baron von Bronsart. Predvedieme ho v rámci tohtoročného zhromaždenia hudobných umelcov v Eisenachu (v polovici júna), ktorého koncerty vo väčšej časti vediem. Avšak pri zdĺhavej ceste celou hudobnou komisiou spolku, ktorú musí dielo absolvovat', dodnes čakám na vyrozumenie. Akonáhle ho dostanem, zašlem Vám ho.

Čo sa týka Vášho diela (prepáčte, ak takýto písomný úsudok nevyznie tak zretelne, ako ho možno formulovat’ v priamej ústnej komunikácii), zaujalo ma vo vel'kej miere svojou svojráznostou, t. j. celkom originálnym jazykom, ktorým hovoríte, o to viac, že mi je vel'mi sympatická tragická, básnická základná myšlienka. Odvážim sa však pochybovat’ o tom, že by získala pri svojej hudobnej realizácii natol'ko zretel'nú podobu, aby mohla pri predvedení rátat’ s bezprostredným porozumením. Ak na jednej strane nepokladám kontrast vel'kých protikladov osudu a ideálu, ktorý je ním napokon premožený, za dost' výstižný, tak stojím, úprimne povedané, značne zarazený pred tematickými skupinami, do ktorých ste vložili Váš „osud“, a ktoré sú sčasti tak zvláštne dýchavičné a roztrieštené, že sa ani v dlhej plodnej výstavbe nevystupňujú k vel'kej katastrofe, ktorá je koniec koncov azda očakávaná. Keďže nie je priložený detailný program, na ktorý sme tu odkázaní, naozaj neviem, čo si mám s nimi počat’. Predstavitelia tunajšej hudby sa totiž delia na dve skupiny, jedni, pre ktorých hudba znamená „výraz" a ktorí ju používajú rovnako ako precízny jazyk, ako je verbálny jazyk, ale na veci, ktorých výraz je práve tomu druhému jazyku odopretý. Tí druhí, pre ktorých je hudba „znejúcou formou“, t. j. vybavia dielo, ktoré komponujú (pokojne bezmyšlienkovite ponechávajúc formu, ktorá už nie je formou, ale pravidlom klasikov), nejakou všeobecnou základnou náladou a rozvíjajú tieto prúdiace témy podla úplne povrchnej hudobnej logiky, pre ktorú mi dnes, ked’̌̌e uznávam iba básnickú logiku, už chýba akékolvek porozumenie.

Programová hudba: - skutočná hudba!

Absolútna hudba: - pomocou určitej rutiny a remeselnej techniky ju môže zhotovit’ každý, aj len do určitej miery muzikálny človek.

Prvá: - pravé umenie!

Druhá: - zručnost'!

Naša dnešná hudba si teda predsa napodiv vzala svoje východisko z č. Il a až Wagner a Liszt ju úplne vedome priviedli k jej pravému určeniu.

Preto my, dnešní mladí hudobníci, ešte stále začíname s č. II, až prídeme na to, že toto ešte vôbec nie je hudba, ale „najpresnejší výraz hudobno-poetickej myšlienky", ktorá 
Wir heutigen jungen Musiker beginnen daher noch immer mit No. II, bis wir dahinter kommen, dass dies noch gar nicht Musik ist, sondern „der präciseste Ausdruck einer musikalisch poetischen Idee", die sich dann ihre Form erst selbst schaffen muss, jede neue Idee ihre eigene neue Form, die Grundbedingung eines musikalischen Werkes ist.

Nun stehe ich bei Ihrem Werke: „Schicksal und Ideal“ allerdings einer neuen eigenartigen Form gegenüber, ohne mir aber über ihren ganz genauen Inhalt positive Rechenschaft geben zu können. Sind Sie, lieber Herr Bella, sich nun des genauen Inhaltes der schon so verschiedenartig aneinandergereihten kleinen Themen, zwischen denen ich (innerhalb der "Schicksal"-Gruppe natürlich, denn über die grossen allgemeinen Gegensätze des „Schicksals" und "Ideals" bin ich mir ja klar) oft eigentlich keinen Zusammenhang finden konnte, vollständig bewusst, so bitte ich Sie, belehren Sie mich und teilen Sie mir ein detailliertes Programm (so weit es eben in Worten möglich ist, eine musikalische Idee, die das innerste Wesen einer Empfindung, die der Wortdichter nur umschreiben kann, sowie einer dramatischen Entwicklung, - die Musik löst auch die nunmehr überwundene Plastik, d. h. die in Stein und Erz, in die lebendige Gebärde auf, siehe Wagner, - anzudeuten) - mit.

Da ich nun in der Deutung und dem innerlichen Erfassen der Programmusik, d. h. der wahren einzigen Musik, ziemlich vertraut bin (in meinem eigenen Schaffen bin ich strengstens bemüht, meine musikalisch poetischen Ideen nach ihrem deutlichen Ausdruck hin zu vertiefen, und habe allen alten Zopfkram von sogenannter Form in meinen drei letzten Werken: 3 sinfonische Dichtungen: Macbeth, Don Juan (nach Lenau), Tod und Verklärung, weggeworfen), fürchte ich fast, dass es Ihnen in diesem Ihrem Werke, das, wie ich höre 74 entstanden und mehrere Male umgearbeitet worden ist, noch nicht so ganz gelungen ist, eine so präcise Tonsprache zu sprechen als eben notwendig, wenn man, wie Sie ganz richtig, auf die äusserliche musikalische Logik in hergebrachter Formel verzichtet, und die dringende Forderung unserer Kunstbestrebungen ist.

Hoffentlich, mein verehrter, lieber Herr Bella, missverstehen Sie mich nicht, und nehmen mir mein aufrichtiges Urteil, das mir nur meine innige Teilnahme an Ihrem künstlerischen Schaffen erpresst hat, nicht übel, ich würde dies aus tiefstem Herzen bedauern. Haben Sie nichts Neues geschrieben? Aus Ihrer letzten Zeit? Kennen Sie Wagner in Ton und Schrift genau? Waren Sie überhaupt in Bayreuth?

Sollte, dies fällt mir eben ein, Ihr Werk nicht durch die grossen Kürzungen, von denen Sie mir schrieben, an Deutlichkeit des Ausdruckes der dichterischen Idee verloren haben?

Bitte, lieber Herr Bella, lassen Sie dadurch, dass ich Ihr mir freundlichst anvertrautes Werk, dass ich eben ganz zur Programmusik nehme, wenn ich es auch als solche für nicht ganz gelungen halte, so offen beurteile, nicht abschrecken, fleissig weiter zu schaffen und mir vielleicht bald ein vollendetes opus zu schicken, zürnen Sie meinem Freimut nicht und seien Sie der aufrichtigsten Teilnahme stets versichert

Ihres treu ergebenen 
si potom ešte len musí sama vytvorit’ svoju formu, každá nová myšlienka svoju vlastnú novú formu, ktorá je základnou podmienkou hudobného diela.

Teraz však pri Vašom diele Osud a ideál stojím pred novou svojráznou formou, ale bez toho, že by som mohol o jej úplne presnom obsahu podat' pozitívnu správu. Nuž milý pán Bella, ak si úplne uvedomujete presný obsah tak nesúrodo zoradených malých tém, medzi ktorými som (prirodzene v rámci skupiny "osudu“, pretože vel'ké všeobecné protiklady „osudu“ a „ideálu“ sú mi predsa jasné) často nemohol nájst” vôbec žiadny súvis, tak Vás prosím, poučte ma a sprostredkujte mi detailný program (samozrejme, pokial' je možné slovne naznačit' hudobnú ideu, najvnútornejšiu podstatu pocitu, ktorý môže básnik slova iba opísat', ako aj dramatického vývoja, - hudba rozpúšta aj teraz už prekonanú sochu, t. j. tú z kameňa i kovu, do živého gesta, pozri Wagner).

Kedže som si teraz do značnej miery osvojil výklad a vnútorné chápanie programovej hudby, t. j. jedinej pravej hudby (vo svojej vlastnej tvorbe sa snažím čo najprísnejšie prehlbovat' moje hudobno-poetické myšlienky podla ich zrejmého výrazu a vo svojich troch posledných dielach, v troch symfonických básňach: Macbeth, Don Juan (podla Lenaua), Smrt' a vykúpenie, ${ }^{33}$ som zahodil všetko staré ozdobné haraburdie tzv. formy), skoro mám obavy, že sa Vám v tomto Vašom diele, ktoré, ako počúvam, vzniklo v roku 74 a bolo niekol'kokrát prepracované, ešte nie celkom podarilo vyjadrit' natol'ko precíznou rečou tónov, ako je práve potrebné, a pritom sa - ako Vy - celkom správne vzdat’ vonkajškovej hudobnej logiky s jej zdedenými formulkami, čo je naliehavou požiadavkou našich umeleckých snažení.

Dúfam, môj ctený, milý pán Bella, že ma nepochopíte zle a nebudete mi mat’ za zlé moje úprimné hodnotenie, ktoré mi vnútil iba môj vrúcny záujem o Vašu umeleckú tvorbu, to by som lutoval z najhlbšieho srdca. Nenapísali ste nič nové? V poslednom čase? Poznáte detailne Wagnerove hudobné i literárne práce? Boli ste vôbec v Bayreuthe?

Práve mi napadá, či Vaše dielo nestratilo práve kvôli vel'kým skráteniam, o ktorých ste mi napísali, zretel'nost'výrazu básnickej idey?

Prosím, milý pán Bella, tým, že tak otvorene posudzujem Vaše dielo, ktoré ste mi prívetivo zverili a ktoré práve úplne považujem za programovú hudbu, hoci ho ako také nepokladám za celkom vydarené, nenechajte sa odradit’ od d’alšej usilovnej tvorby a možného skorého zaslania dokončeného opusu, nehnevajte sa na moju úprimnost’ a budte nad’alej uistený o najúprimnejšom záujme

Vášho verne oddaného 
Herrn Joh. Leop. Bella, Dirigent des Musikvereins Hermannstadt.

Lieber Herr Bella!

Für heute die Nachricht, daß Ihr "Schicksal und Ideal“ mit ziemlicher Bestimmtheit zur Aufführung auf der im Juni stattfindenden Versammlung des allgemeinen Tonkünstlervereines in Eisenach unter meiner Leitung angenommen ist.

Haben Sie meinen Brief erhalten?

Herzlichste Grüsse Ihres aufrichtig ergebenen

Richard Strauss

Sind Sie schon Mitglied des allgem. deutschen Tonkünstlervereines?

9

Hermannstadt in Siebenbürgen, 25. 4. 1890

Hochverehrter Herr Hofkapellmeister!

Ihre gütige Mitteilung über meine sinfonische Dichtung hat mich freudig überrascht, und wenn die in Aussicht gestellte Hoffnung auch in Erfüllung gegangen sein wird, will ich mich noch mehr darüber freuen, dass dann Ihr strenges Urteil doch einige nicht unwesentliche Änderungen zu Gunsten des Werkchens sich gern gefallen lassen wird. Sie entnehmen daraus die Bestätigung, dass ich Ihren letzten Brief, - diesen neuen grossen Beweis Ihrer Teilnahme, für die ich Ihnen tiefsten Dank sage, - wohl erhalten, aber nur aus dem Grunde noch nicht beantwortet habe, weil ich an der Influenza erkrankt und durch lange Nachwirkung derselben fast bis jetzt - seit Weihnacht - ununterbrochen leidend, nur mühselig meinen Pflichten, die sich gar übermässig aufgehäuft hatten, entsprechen und deshalb auch meine zwar sofort noch im März begonnene, aber sehr ausführlich angelegte Antwort nur hin und wieder mit einigen angestückelten Worten fortsetzten konnte. Da ich überdies an einem Erfolg bei dem „Allgem. d. Tonkünstlerverein“ umsoweniger gedacht, als derselbe schon vorher bei Ihnen gescheitert war, so wollte ich mir erst Zeit lassen, um mich Ihnen gegenüber ganz auszusprechen. Ihre neueste freundliche Nachricht zwingt mich nun, in Kürze den Versuch zu unternehmen, Ihre Ansicht zu Gunsten meiner Arbeit nach Möglichkeit umzustimmen.

Meine sinfonische Dichtung steht noch heute als treues und einheitlich abgeschlossenes Abbild dessen vor mir, was mich als mein eigenes Schicksal süss und schaurig betroffen hat. Nach Allem, was sich mit mir endlich ereignet hatte, habe ich auch mit der Welt gebrochen, und mein Werkchen entstand in jener Lebenspause, während welcher mein ganzer Sinn nur noch der Musik sich zuwandte. So entlud sich damals darin meine ganze Stimmung urwüchsig und ohne jedwede Absicht. Später gab ich dann dem Tonbilde - noch unter dem Zwang der alten Ansicht - eine sehr weitschweifige, aber ziemlich schulgerechte Form eines sinfoni- 
8 Pohladnica Richarda Straussa Jánovi Levoslavovi Bellovi

Weimar 19. apríla 1890

Nemecká ríšska pošta

pohladnica

Pán Ján Levoslav Bella, dirigent Hudobného spolku v Sibini

Milý pán Bella!

Pre dnešok správa, že Váš Osud a ideál je takmer isto prijatý na predvedenie na júnovom zhromaždení Všeobecného spolku hudobných umelcov v Eisenachu pod mojím vedením.

Dostali ste môj list?

Najsrdečnejšie pozdravy Vášho úprimne oddaného

Richarda Straussa

Ste už členom Všeobecného nemeckého spolku hudobných umelcov?

9 List Jána Levoslava Bellu Richardovi Straussovi

Sibiň v Sedmohradsku, 25. apríla 1890

Velavážený pán dvorný kapelník!

Vaša láskavá správa o mojej symfonickej básni ma radostne prekvapila, a ked’sa aj naplní tá predostretá nádej, budem sa ešte viac tešit z toho, ak vo svojom prísnom posudku následne rád urobíte niekolko nie nepodstatných zmien v prospech dielka. $Z$ toho môžete vyrozumiet', že som Váš posledný list - tento nový vel'ký dôkaz Vášho záujmu, za ktorý Vám vyjadrujem svoju najhlbšiu vd'ačnost' - dostal v poriadku, ale som naň ešte neodpovedal iba z toho dôvodu, že som dostal chrípku a kvôli jej dlhodobým následkom skoro doteraz - od Vianoc - nepretržite trpiac, som si iba s námahou mohol plnit svoje povinnosti, ktoré sa príliš nakopili, a preto som aj v mojej hoci ešte $v$ marci začatej, ale vel'mi podrobne rozvrhnutej odpovedi iba z času na čas niekol'kými doplnenými slovami mohol pokračovat'. Kedže som okrem toho tým menej myslel na úspech vo Všeobecnom nemeckom spolku hudobných umelcov, ked' tento už predtým u Vás stroskotal, tak som si chcel najskôr nechat' čas, aby som sa Vám úplne zdôveril. Vaša najnovšia láskavá správa ma teraz núti pokúsit' sa Vás podla možnosti v krátkosti presvedčit', aby ste zmenili mienku v prospech mojej práce.

Moja symfonická báseň stojí ešte dnes predo mnou ako verný a ucelený obraz toho, čo ma sladko aj strašne stihlo ako môj vlastný osud. Po tom všetkom, čo sa so mnou napokon udialo, som skoncoval aj so svetom, a moje dielko vzniklo $v$ tej životnej prestávke, počas ktorej sa celá moja mysel' obrátila už len $\mathrm{k}$ hudbe. Tak sa vtedy v nej prirodzene uvol'nil celý môj stav mysle bez akéhokolvek zámeru. Neskôr som dal hudobnému obrazu - ešte pod tlakom starého pohl'adu - vel'mi rozvláčnu, ale pomerne akademickú formu prvej symfonickej časti, z čoho sa postupom času 
schen ersten Satzes, woraus mit der Zeit eine Riesen-Sinfonie werden sollte! Da jedoch mein eingehendes Studium der modernen Musik endlich auch meine Kunstansicht geklärt hatte, so machte ich mich daran, aus dem Werk Alles zu entfernen, was ich demselben als blosse Wiederholung des bereits einmal Ausgesprochenen aufgezwungen hatte, und nun steht es da, wie es in Wahrheit nicht anders werden durfte. Nur seine Aufschrift "Schicksal und Ideal“ ist zu allgemein und kann Missverständnis verschulden. Da ich davor schauderte, was der Welt gänzlich verborgen war und sich nur unter vier Augen mit furchtbaren Folgen für mich (Anfangs, - denn jetzt bin ich innerlich glücklich!) abgespielt hatte, durch einen passenderen Titel zu verraten und zu enthüllen, - so sann ich auch gar nicht nach einem genauen Programm und Titel und verbarg die ganze Sache unter einer sehr weiten Maske. Nun sehe ich wohl ein, wie notwendig ein Programm überhaupt ist, - wenn eine unzutreffende, viel und nichts sagende Bezeichnung Ursache wird, sich gedanklich geradezu von der wahren Fährte zu entfernen. So will ich nun kurz das Ganze nach Tunlichkeit enthüllen und bin überzeugt, dass Sie mich dann von einem Teil der mit entgegengehaltenen Sünden freundlichst freisprechen werden.

Unter Ideal ist hier Liebe allein und ausdrücklich das Ideal der schönsten Form des Lebens, Liebe als Stifterin der Familie zu verstehen. Wenn Sie sich an meine Vergangenheit erinnern, so fällt Ihnen auch sofort der ungeheure Zwiespalt des mir beschiedenen Schicksals auf, das mir jeden Gedanken an Liebe untersagte, ja denselben zum Verbrechen stempelte - und mich dennoch dämonisch zwang, dem erkannten und mir vollbewussten Ideale unwiderstehlich nachzuringen. Gleichem Lose unterliegt das Weib, dessen Liebe zu mir unerlaubt ist; - lange half sie meinem Kämpfen um sie, - bis ihre Kraft brach und mein ganzes Ringen vergeblich wird. Für die musikalische Darstellung des daraus entstehenden Stoffes dienten - abgesehen von einer vorübergehenden Episode - ausschliesslich drei Motive:

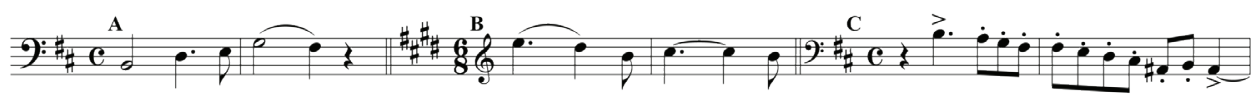

A) Schicksal, B) Ideal und C) das die Vereinigung feindselig hindernde Element.

Der poetische Inhalt wäre für einen geeigneten Dichter vielleicht geradezu denkbar, aber ich muss mich begnügen, den Gedankengang nur kurz anzudeuten.

Im einleitenden Maestoso erscheint das Schicksalsmotiv in der Schwere seiner Tragweite für das Ganze, - Ahnungen von Kampf und Leid, aber auch ein kühner Wille sind in seinem Gefolge. Einen Geächteten treibt eine dunkle Kraft nach Hohem, Freiheit und Glück zu ringen; ein süsses Bild, - menschenwürdiges Dasein in dessen' Besitz - zieht ihn gewaltig hinan, - es neigt sich ihm zu, - aber auch seine Fesseln müssen vorher gelöst werden.

Das folgende Allegro bringt das Schicksalsmotiv im Gegensatz zu den feindlichen Mächten, welche gleichsam vor ihm zurückweichen; vor dem Schlusse, im Übergang zum Andante (A-dur 4/4) antwortet dem Schicksalsmotiv ein Wiederhall, der sich im nachfolgenden Andante (A-dur 4/4) als Übersetzung des Schicksalsmotivs ins Weibliche darstellt und darum gleichsam als Trost und Verheissung einen milderen, freundlicheren Ausdruck erhält:

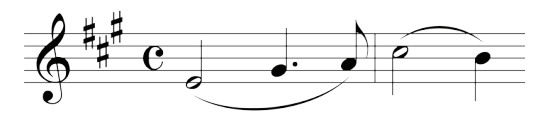

Neu gestärkt bäumt sich nun das Hauptmotiv mehrfach gegen die aufs neue anrückenden feindseligen Mächte auf, es folgt Kampf und Leid, - der Wolkenschleier zerreisst, - Der 
mala stat' gigantická symfónia! Kedže však podrobné štúdium modernej hudby konečne vyjasnilo aj môj umelecký názor, podujal som sa odstránit z diela všetko, čo som mu vnútil ako číre opakovanie už raz vysloveného, a teraz vyzerá tak, akoby vlastne iné ani nemalo byt'. Iba jeho názov Osud a ideál je príliš všeobecný a môže spôsobit' nedorozumenie. Kedže som sa desil toho, že priliehavejším titulom prezradím a odhalím to, čo bolo pred svetom celkom skryté a odohrávalo sa len medzi štyrmi očami so strašnými následkami pre mňa (spočiatku, lebo teraz som vnútorne štastný!), nemyslel som vôbec na presný program ani na titul a skrýval som tú celú vec pod vel'mi širokou maskou. Teraz zaiste uznávam, aký dôležitý je program vo všeobecnosti, ked'Vás nevhodné, vel'a a nič nehovoriace pomenovanie myšlienkovo priam odkloní od správnej stopy. Tak chcem podla možnosti všetko stručne odkryt' a som presvedčený, že ma potom vlúdne oslobodíte od časti mne vytýkaných hriechov.

Pod ideálom tu treba rozumiet jedine a výslovne lásku, ideál najkrajšej formy života, lásku ako zakladatel'ku rodiny. Ak si spomeniete na moju minulost', hned' Vám napadne úžasný rozpor medzi osudom, ktorý sa mi stal údelom a ktorý mi zakazoval akúkolvek myšlienku na lásku, ba ju vyhlasoval za zločin - a predsa ma démonicky nútil zápasit neústupne o spoznaný a plne uvedomovaný ideál. Rovnakému osudu podlieha žena, ktorej láska ku mne nie je dovolená; dlho pomáhala môjmu boju o ňu, až sa jej sila zlomila a celý môj zápas sa stal márnym. Na hudobné stvárnenie z toho vznikajúcej látky slúžili - odhliadnuc od prechodnej epizódy - výlučne tri motívy:

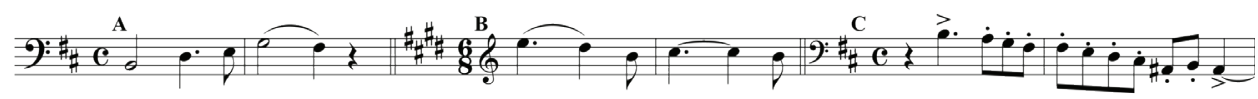

A) Osud, B) Ideál, C) nepriatel'ský prvok brániaci zjednoteniu.

Možno nejaký súci básnik by vedel zosnovat' nejaký poetický obsah, ale ja sa musím uspokojit’ s tým, že len stručne naznačím myšlienkový pochod.

V úvodnom Maestoso sa objavuje osudový motív v taživosti svojho dosahu na celok - sprevádza ho predtucha boja a utrpenia, ale aj odvážne odhodlanie. Vyhnanca ženie temná sila bojovat' za výšiny, slobodu a štastie; sladký obraz - bytie dôstojné človeka $v$ jeho dosahu - ho mocne pritahuje, prikláňa sa $\mathrm{k}$ nemu, ale aj jeho putá sa musia predtým uvol'nit'.

Následné Allegro prináša osudový motív v protiklade k nepriatel'ským mocnostiam, ktoré takpovediac od neho ustupujú; pred koncom, v prechode $k$ Andante (A dur 4/4) odpovedá osudovému motívu ozvena, ktorá je v nasledujúcom Andante (A dur 4/4) znázornená ako premietnutie osudového motívu do ženského princípu, a preto takpovediac ako útecha a zaslúbenie získava miernejší, priatel'skejší výraz:

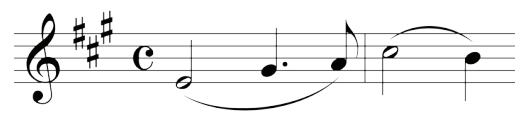

Nanovo posilnený hlavný motív sa teraz niekol'kokrát vzpiera proti znovu postupujúcim nepriatel'ským mocnostiam, nasleduje boj a utrpenie, závoj mračien sa trhá, 
Liebesgedanke strahlt immer heller hervor und kann endlich im Allegretto (E-dur 6/8) sein hohes Lied anstimmen. Beide Motive, Schicksal und Ideal, vereinigen sich hier (Takt 4.a und b) - und ein Teil des

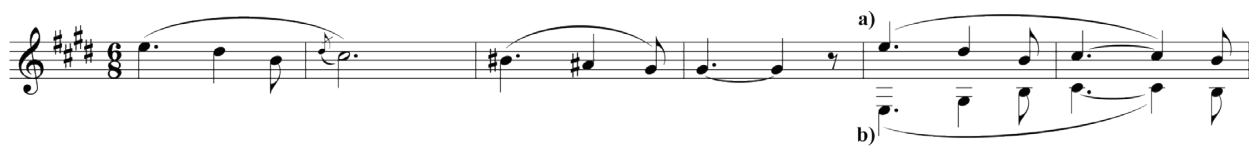

Schicksals findet Erfüllung im gegebenen, ausgesprochenen Wort der Liebe.

Doch kaum hat dieses Wort der Liebe Zeit zu enden, schon weht ein eisiger Schauer hinein und das Wort der Liebe wird verneint (in den Fagottstimmen), gebrochen, verraten. Die diesem Satze (Agitato, 4/4 e-moll) untergelegte Syncope

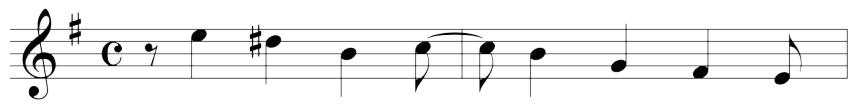

und das zuerst von den Fagotten gebrachte Motiv

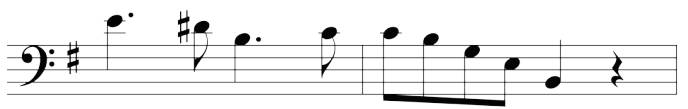

sind offenbar Umwandlungen des idealen - oder (Liebes-) Motivs: Syncope und das verneinte Liebesmotiv steigern sich, - wie zu einem Heldengebet umgestaltet erhebt sich dagegen choralartig das Schicksalsmotiv in den Hörnern

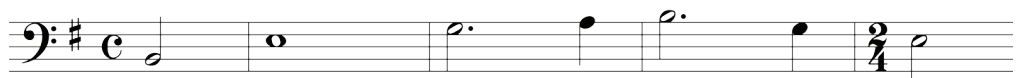

um bald in blinkender Rüstung fast siegreich aufzutreten:

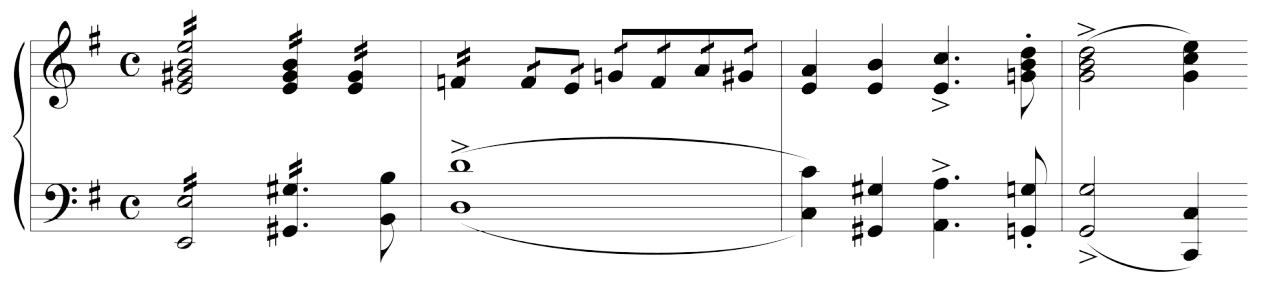

Nun folgt Bekämpfung des Verrates, in zerknirschtes Schluchzen zerbröckelt das Lied der Liebe:

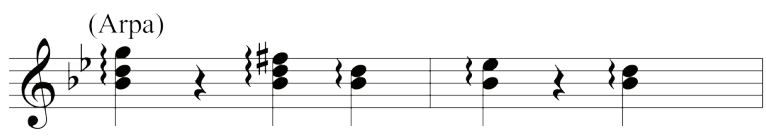

und wenn auch himmelan dringt des ringenden Helden Klageruf:

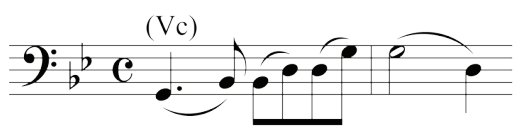


myšlienka lásky žiari čoraz jasnejšie a konečne môže v Allegrette (E dur 6/8) zanôtit’ svoju vel'pieseň. Oba motívy, osud a ideál, sa tu zjednocujú (Takt 4a a b) - a čast'

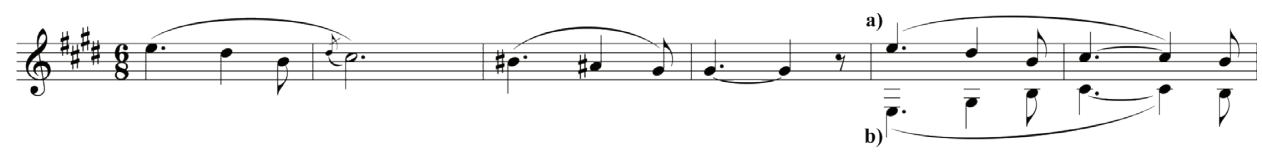

osudu nachádza naplnenie v danom, vyslovenom slove lásky.

Avšak toto slovo lásky má sotva čas odzniet', už veje ladová spŕška a slovo lásky je popreté (vo fagotoch), zlomené, zradené. Synkopa a), o ktorú sa opiera tento úsek (Agitato, 4/4 e mol)

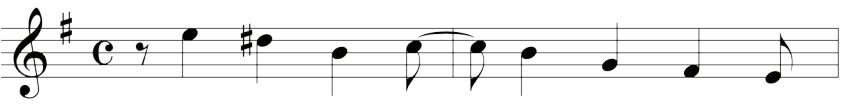

a motív b) zahraný najskôr fagotmi

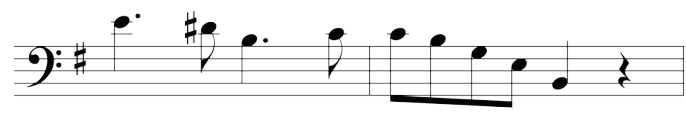

sú zjavne premenami ideálneho (či lúbostného) motívu: Synkopa a popretý motív lásky sa stupňujú, - naproti tomu sa chorálovito vznesie motív osudu v lesných rohoch, premenený akoby na modlitbu hrdinu,

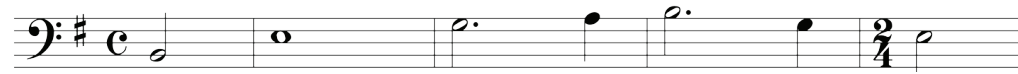

aby čoskoro takmer vítazne nastúpil v lesknúcej sa zbroji:

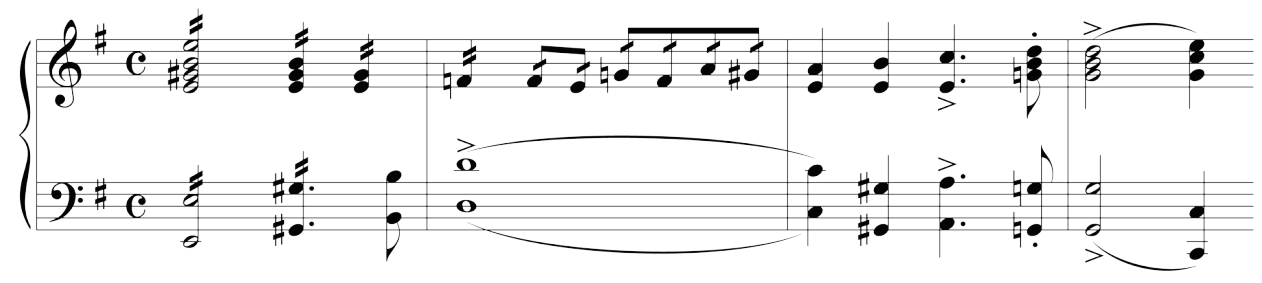

Nato nasleduje boj proti zrade, pieseň lásky sa rozdrobí na sklúčený vzlykot

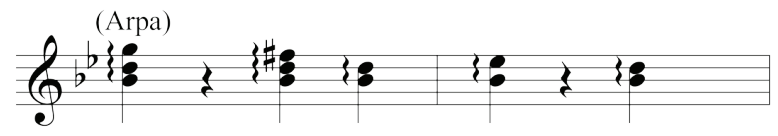

a aj ked' k nebu preniká žalostné volanie zápasiaceho hrdinu,

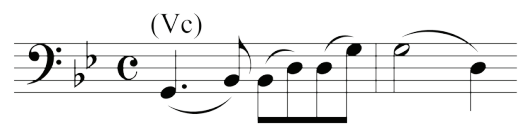


so bleibt er sich dennoch im Kampfe um seine Liebe treu und fest:

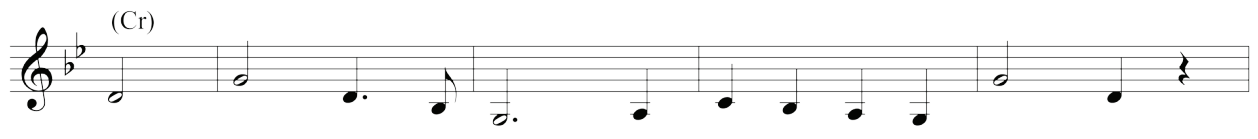

und die noch so gesteigert stürmenden feindseligen Mächte verstummen, während das Schicksalsmotiv neuerdings in freundlichere Regionen einzieht:

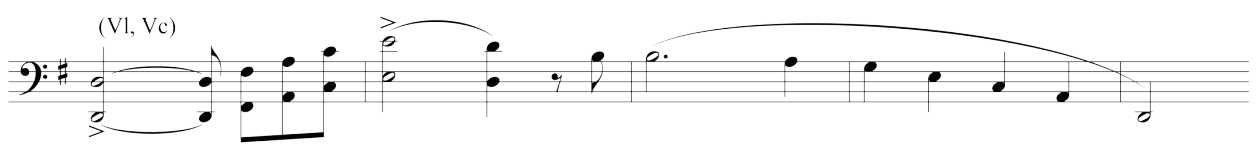

da erwacht die Erinnerung an das Liebeswort, es tritt ein Augenblick des Friedens, der Rast, der Sammlung ein, (Episode: G-dur 3/4), wo gleichsam die erregten Stimmungen in das neutrale Gebiet entsagender Freundschaft auslaufen. Doch kaum beginnt hier im più mosso die begleitende Harfe einen wärmeren Puls zu schlagen, - schon regen sich dagegen (Posaunen!) die feindseligen Kräfte, - aber auch der Spruch des Schicksals entsteigt der dunklen Tiefe (Fag., Horn und Tuba) und wenn auch zuerst zaghaft und verschleiert:

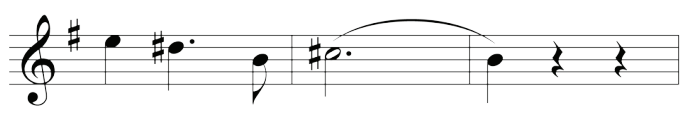

so erscheint dennoch sofort darauf in seiner ursprünglichen Reine und Helle das Ideal:

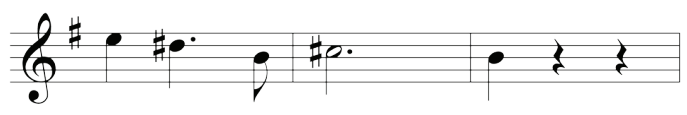

dass grollend darob die feindlichen Elemente immer heftiger in den Bässen aufschäumen, und bald im kommenden Allegro ( $\mathrm{H}$-moll 4/4) das alte Ringen aufs Neue und heftiger losgeht. Von Scharen hohnlachender Dämonen gehetzt, toben die feindseligen Mächte, - es entbrennt ein gesteigerter Kampf, - aber in klägliche Verzweiflung wandelt sich das Idealmotiv, und aus dem verheissungsvollen A-dur Andante des Anfangs, wird in dem jetzt eintretenden Andante (As-dur 4/4), zuerst Klarinett-Solo, dann weiter Oboe-Solo in H-dur), welches ebenso wie das erstere eine Übersetzung des Schicksalsmotives ins Weibliche sein will, eine Szene des Abschiedes. Das Weib erlahmt im Ringen um gemeinsames Glück und gibt seine Liebe auf. Wie ein Traumgebilde taucht das Idealmotiv noch einigemal hervor, auch noch diesen Traum der Erinnerung sucht der Held des Poems einmal zu haschen:

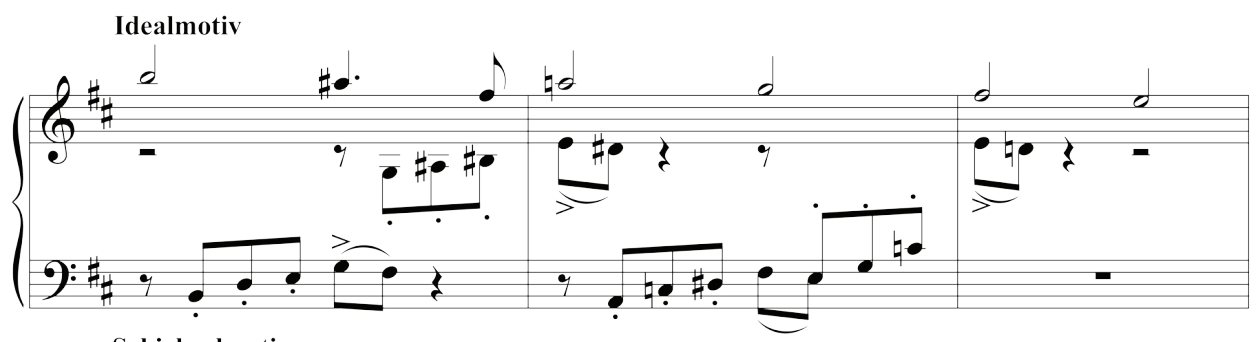

Schicksalmotiv 
tak predsa ostáva v boji o svoju lásku verný a nepoddajný

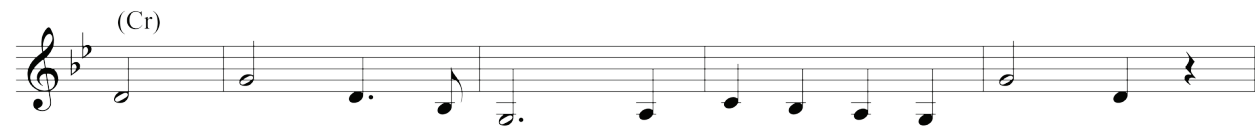

A tie čoraz väčšmi sa stupňujúce útoky nepriatel'ských mocností zmíknu, zatial' čo osudový motív znova vstúpi do priatel'skejších sfér.

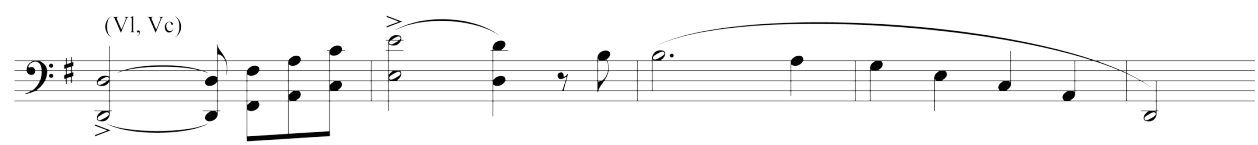

Tu sa prebúdza spomienka na slovo lásky, nastáva okamih mieru, oddychu, sústredenia (epizóda G dur 3/4), kde vzrušené nálady takpovediac vstúpia do neutrálneho územia asketického priatel'stva. Avšak sotva tu v più mosso začne sprievodná harfa bit’ vrúcnejším tepom, už sa proti tomu dvíhajú nepriatel’ské sily (trombóny!), ale aj ortiel' osudu vystúpi z temnej híbky (fagot, lesný roh a tuba) a aj ked’spočiatku váhavo a zastreto,

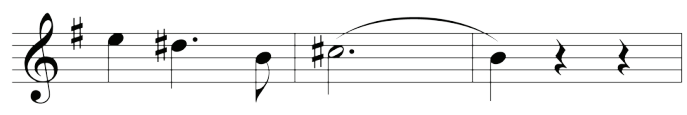

tak sa predsa hned'na to objaví ideál vo svojej pôvodnej čistote a jase,

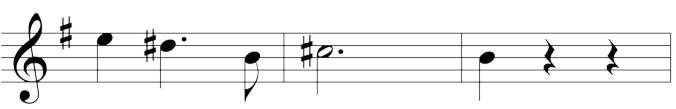

kým nepriatel'ské elementy rachotia a čoraz mocnejšie kypia v basoch, a čoskoro sa v nastupujúcom Allegre (h mol 4/4) začína starý súboj nanovo a zúrivejšie. Nepriatel'ské mocnosti besnejú, štvané zástupmi vysmievajúcich sa démonov, vzplanie stupňujúci sa boj, ale motív ideálu sa premení na žalostné zúfalstvo a z nádejného počiatočného Andante A dur sa stáva v práve nastupujúcom Andante (As dur 4/4) - najprv v sóle klarinetu, potom v sóle hoboja v $\mathrm{H}$ dur - ktoré chce takisto ako to prvé byt' premietnutím osudového motívu do ženského princípu, scénou rozlúčky. Žena ochabuje v zápase o spoločné štastie a vzdáva sa svojej lásky. Ako prelud sa vynorí motív ideálu ešte niekol'kokrát; tento sen spomienky sa hrdina básne snaží uchopit’ ešte raz,

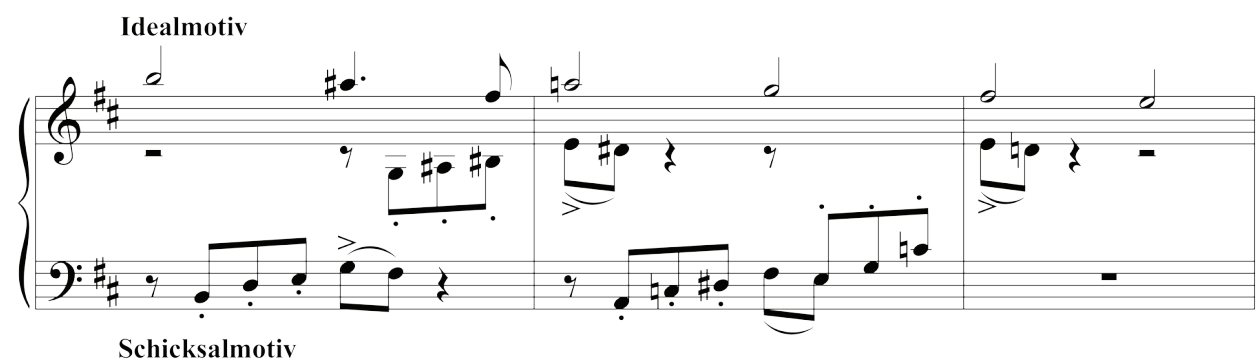


doch sein Schicksal ist entschieden und sein Ringen und Kämpfen zuletzt noch von lachenden Dämonen gehöhnt, zerschellt an seiner Bestimmung.

Wenn ich mir den Titel „Schicksal und Ideal“ von Augen halte, - so begreife ich's allerdings, dass man sich in der Composition programmässig nicht zurechtfinden kann. Und dennoch weiss ich mir gar nicht zu helfen, - denn so geradezu darf ich meine Herzensgeschichte doch nicht auf den Pranger stellen!

Dass Ihnen durch die gegebene Erläuterung meine Arbeit, die für mich ein notwendiger und heilsamer Herzenserguss war, viel näher gerückt erscheinen wird, daran zweifle ich keinen Augenblick, - wenn ich es mir auch durchaus nicht verhehle, dass Sie mit der musikalischen Wiedergabe einzelner Details wenig oder gar nicht zufrieden sein können. Wie oft habe ich, - um z. B. Härten zu vermeiden, sogar charakteristisch notwendige Intervalle in allerzahmste akkordeigene Töne verwandelt; ja, - selbst den Abschluss des Allegretto (E-dur 6/8), der hier - eigentlich auf V-7 abbrechen und sofort durch plötzlichen Eintritt des unerwarteten e-moll überrumpelt werden sollte, - mache ich gegen die poetische Voraussetzung langweilig genug zuerst in E-dur, - wie ein gehorsamer Schüler! - um dem Eintritt einer förmlichen Katastrophe fast die ganze mörderische Bedeutung zu rauben! Aber ich bin fest überzeugt, dass, abgesehen von den Mängeln der Detailzeichnung, das Werkchen im Ganzen den Stempel der Wahrheit an sich trägt und ein musikalisches Gemüt ergreifen muss, - wie es trotz aller langweiligen Breitspurigkeit der damaligen Fassung dieser Partitur bei der ersten Aufführung in einem philarm. Conzert in Prag vorgekommen ist. Was auf dem Papiere auf den ersten Anblick in unscheinbare Sätzchen zersplittert erscheint, - das sind nur Winke für den Dirigenten und das Orchester, - denn alle die teilenden Doppelstriche, - die eigentlich nur selten irgend einen Satzeinschnitt bedeuten, und ebenso die Abwechslungen im Tempo, die zumeist durch ein accelerando oder ritartando vorbereitet werden, gehen ja als solche eigentlich spurlos am Zuhörer vorüber, an dessen Ohr in ununterbrochener rascher Entwicklung eine gedrungene Tragödie vorüberrauscht.

Ich bedaure sehr, keine Abschrift der Partitur - wie sie jetzt eingerichtet ist, zur Hand gehabt zu haben, - hoffe aber dennoch deutlich genug die Bedeutung und Stellung des Einzelnen im Ganzen bezeichnet zu haben, so dass nach der programmässigen Deutung der Hauptmotive auch die Logik des Ideenganges zu ihrem Recht kommen muss. Wird das Schicksalsmotiv als das vom Schicksal bestimmte Ringen nach Vereinigung mit dem Ideal mit tragischem Ausgang erfasst, - dann schadet es dem musikalischen Erfolg gar nicht, wenn z. B. verkannt würde, dass als Träger dieser Bestimmung ein Held und eine Heldin anzunehmen sind, und dass unter dem Ideal die Liebe im angedeuteten Sinne sich birgt. Selbst in solcher Beschränkung des Programms erscheint mir die Form motiviert und fasslich genug, um heraushören zu können, wie die Entwicklung logisch vor sich geht:

1. Hauptgedanke: Entschluss oder Bestimmung: nach Vereinigung mit dem Ideal zu ringen;

2. Feindseliges stürmt heran;

3. aus der Berührung mit dem Feindseligen geht der Hauptgedanke in lichterer Gestalt hervor;

4. Angesichts des Feindseligen unternimmt dieser sofort den Kampf aufs Neue;

5. nach dem Kampf Klärung der Situation, der Hauptgedanke färbt sich wärmer, das Bild des Ideals tritt hervor;

6. Vereinigung des Hauptgedanken mit dem Ideal;

7. Verdüsterung - Verneinung des Ideals;

8. Berührung des Hauptgedankens mit diesem neuen Gegensatz, dem sich am Schlusse das Feindselige (von 2.) mächtig zugestellt;

9. Der Hauptgedanke geht daraus verklärt hervor, das Ideal neigt sich ihm zu; 
ale o jeho osude je rozhodnuté a jeho zápas a boj naposledy ešte vysmievaný chechtajúcimi sa démonmi, sa roztriešti na jeho údele.

Ked' mám však pred očami titul Osud a ideál, chápem, že v kompozícii sa nedá programovo zorientovat'. A napriek tomu si vôbec nemôžem pomôct́, pretože predsa nesmiem tak otvorene postavit’ na pranier príbeh môjho srdca!

Nepochybujem ani na okamih, že sa Vám vd’aka danému vysvetleniu bude moja práca, ktorá bola pre mňa potrebným a liečivým výlevom srdca, javit' ovel’a bližšia, aj ked' vôbec netajím, že nemôžete byt' celkom alebo vôbec spokojný s hudobným zobrazením jednotlivých detailov. Často - napríklad, áno, aby som sa vyhol istej tvrdosti, zmenil som dokonca charakteristicky potrebné intervaly na najmiernejšie akordické tóny - dokonca záver Allegretta (E dur 6/8), ktorý by sa tu vlastne vo V-7 mal zlomit’ a hned' by ho mal zaskočit’ náhly nástup nečakaného e mol, - pokračujem napriek poetickému predpokladu dost' nudne najprv v E dur, - ako poslušný žiak! - aby som nástup skutočnej katastrofy zbavil takmer celého jej vražedného významu! Som však pevne presvedčený, že odhliadnuc od nedostatkov v kresbe detailov, dielko nesie celkovo pečat' pravdivosti a musí pohnút' muzikálnou myslou, čo sa prihodilo napriek všetkej nudnej širokej rozvláčnosti vtedajšieho znenia tejto partitúry pri premiére na filharmonickom koncerte v Prahe. Čo sa na papieri javí na prvý pohlad rozdrobené na nepatrné vetičky, to sú len pokyny pre dirigenta a pre orchester, pretože všetky tie deliace dvojité taktové čiary, ktoré vlastne iba zriedka znamenajú nejaký zásah do časti, a takisto tempové zmeny, ktoré sú zväčša pripravované accelerandom alebo ritardandom, vlastne ako také prejdú bez stôp okolo poslucháča, popri uchu ktorého v nepretržitom rýchlom vývoji prehrmí masívna tragédia.

Vel'mi lutujem, že som nemal po ruke žiadnu kópiu partitúry, tak ako je upravená teraz, napriek tomu však dúfam, že som dostatočne zrozumitelne označil význam a postavenie jednotlivostí v rámci celku, takže po programovom rozbore hlavných motívov musí príst' k slovu aj logika myšlienkového pochodu. Ak sa osudový motív chápe ako zápas ustanovený osudom o zjednotenie s ideálom s tragickým vyústením, potom hudobnému úspechu vôbec neuškodí, ak by napríklad ostalo nepochopené, že za nositelov tohto osudu treba pokladat' hrdinu a hrdinku a že pod ideálom sa skrýva láska v naznačenom zmysle. Dokonca aj pri takomto obmedzení programu sa mi forma javí ako dostatočne motivovaná a zrozumitel'ná, aby bolo možné počut', ako logicky prebieha vývoj:

1. Hlavná myšlienka: rozhodnutie alebo osud: zápasit’ o zjednotenie s ideálom;

2. prihrmí nepriatel'ský prvok;

3. z dotyku s nepriatel'ským prvkom vychádza hlavná myšlienka v jasnejšej podobe;

4. zoči-voči nepriatel'skému prvku táto (hlavná myšlienka) okamžite podnikne zápas nanovo;

5. po boji vyjasnenie situácie, hlavná myšlienka sa sfarbí vrúcnejšie, predstúpi obraz ideálu;

6. zjednotenie hlavnej myšlienky s ideálom;

7. stemnenie - popretie ideálu;

8. dotyk hlavnej myšlienky s týmto novým protikladom, ktorému sa na konci nepriatel'ský prvok (z 2.) mocne postaví;

9. hlavná myšlienka vychádza z toho očistená, ideál sa k nej prikláňa; 
10. eine friedliche Episode, - sie wird durch das Feindselige gestört, - der Hauptgedanke erhebt sich in düsterer Gestalt, - das Ideal erglänzt ihm noch einmal in voller Klarheit;

11. nach dieser Berührung aller drei Hauptmotive vermehrter Kampf;

12. das Ideal erscheint verzerrt;

13. der Hauptgedanke zu klagendem Gesang erweitert (Klarinett-Solo in As);

14. tragischer Ausgang des Hauptmotivs, worin hin und wieder die Erinnerung an das Ideale ganz traumhaft erscheint.

Bei der Kürze der Form und der durch fast keine Umwandlung verkennbaren Deutlichkeit der vorkommenden drei Hauptmotive denke ich - wohlbemerkt: 1874! - mit meiner Dichtung, oder besser: musikalisch poetischen Nachgestaltung jener inneren und äusseren Vorgänge, die mich wieder als Menschen der Welt zugeführt haben, und deren erste Lösung für mich tragisch ausgefallen war, keinen so misslungenen Beitrag auf einem Gebiete versucht zu haben, das noch lange unter allen Künsten das allerschwierigste bleiben wird. Darum freue ich mich auch offenherzig über Ihre unumwundenen Ausstellungen, - deren gänzliche Berechtigung Sie vielleicht jetzt meinem Programm gegenüber weniger scharf festhalten werden; denn sie sind mir ein ehrender Beweis, dass Sie fast von mir erwarten, ich möchte mich zu Ihrer Höhe aufschwingen! Doch auch die kleineren Bausteine haben ihre grosse Berechtigung, - und ich bin glücklich, wenn auch meiner in den Bau mit hinein darf!

Sollte es zweckdienlich sein, meine Zeilen zu Aufklärung über das Werkchen den betreffenden Persönlichkeiten mitzuteilen, - so wollen wir darüber gütigst nach Gutdünken verfügen; nur wollen Sie vielmals entschuldigen, dass es mir unmöglich war, das Ganze stilistisch und äusserlich würdiger und schicklicher zu bieten. Ich bin ein sehr gequälter Mann!

Mitglied des allg. d. Tonkünstlervereines war ich noch nicht - obgleich ich es längst mir vorgenommen hatte; aber ich will mich beeilen, mit die Mitgliederschaft sofort zu erwerben.

In aufrichtigster Verehrung und mit den herzlichsten Grüssen

Ihr dankbarster

Bella

10

München, den 11. Juli 90

Mein lieber Herr Bella!

Nach dem anstrengenden Musikfest in Eisenach und einem Besuche in Bayreuth hier im Elternhause etwas zur Ruhe gekommen, muss ich Ihnen doch über den Verlauf Ihrer Aufführung Nachricht geben (sie fand am 22. 5. 1890 statt). Das Programm, das ich Ihnen sandte, haben Sie wohl erhalten. Vor allem: Ihr Werk ist sehr gegangen (und wären Sie, glaube ich, mit der Wiedergabe zufrieden gewesen) und fand Beifall. Dank Ihrem Programm war ich mir vollständig klar über das Stück und habe es, so darf ich wenigstens hoffen, nach Ihren Intentionen herausgebracht. Den Eindruck, den ich aber zuerst beim Studium Ihres Werkes hatte, dass es im poetischen Inhalt zu detaillirt und ohne ganz genaues Programm schwer verständlich ist, fand ich nach der Aufführung bei vielen Musikern bestätigt. Ich glaube, Sie müssten für künftige Aufführungen ein ganz bestimmtes dichterisches Programm Ihrem Werke voranschicken, ich hatte von Ihrer Seite keine Vollmacht, aus Ihrem Brief eines zusammenzustellen, es wäre für mich auch eine schwierige Sache, ich glaube, Sie müssen sich wohl selbst dazu entschließen. 
10. pokojná epizóda, narúša ju nepriatel’ský prvok, hlavná myšlienka sa zdvihne v temnej podobe, ideál jej zažiari ešte raz v plnom jase;

11. po tomto dotyku rozšírený boj všetkých troch hlavných motívov;

12. ideál sa zjavuje znetvorený;

13. hlavná myšlienka rozšírená na žalobný spev (sólo klarinetu v As);

14. tragické vyústenie hlavného motívu, v ktorom sa tu a tam úplne ako vo sne zjavuje spomienka na ideál.

Pri krátkosti formy a skoro žiadnou premenou nepoznačenej zrozumitel'nosti troch vyskytujúcich sa hlavných motívov si myslím - nota bene: 1874! -, že som sa mojou básňou, alebo lepšie, hudobno-poetickým stvárnením tých vnútorných a vonkajších udalostí, ktoré ma prinavrátili svetu ako človeka, a ktorých prvé riešenie dopadlo pre mňa tragicky, nepokúsil o až natol'ko nevydarený príspevok v oblasti, ktorá ešte dlho ostane najzložitejšou medzi všetkými druhmi umenia. Preto sa aj úprimne teším z Vašich priamych kritických poznámok, na ktorých úplnej oprávnenosti možno teraz vzhladom na môj program nebudete trvat’ až tak prísne; pretože tieto sú mi poctou a dôkazom, že skoro odo mňa očakávate, že sa povznesiem na Vašu úroveň! Ale predsa aj menšie stavebné kamene majú svoje vel'ké opodstatnenie a som štastný, ak aj ten môj smie byt' súčastou stavby!

Ak by malo byt' účelné kvôli objasneniu dielka sprostredkovat’ moje riadky príslušným osobnostiam, môžete s tým láskavo disponovat’ ako uznáte za vhodné, len prosím mnohokrát o odpustenie, že mi nebolo možné podat' to celé štylisticky a formálne dôstojnejšie a vhodnejšie. Som vel'mi utrápený človek!

Členom Všeobecného nemeckého spolku hudobných umelcov som sa ešte nestal - hoci som si to dávnejšie predsavzal; ale chcem sa poponáhl'at' ihned' získat' členstvo.

S najúprimnejšou úctou a s najsrdečnejšími pozdravmi

Váš najvd’ačnejší

Bella

10 List Richarda Straussa Jánovi Levoslavovi Bellovi

Mníchov, 11. júla 1890

Môj milý pán Bella!

Po tom, čo som si po namáhavých hudobných slávnostiach v Eisenachu a návšteve $v$ Bayreuthe trocha odpočinul tu v rodičovskom dome, musím Vám predsa podat' správu o priebehu Vášho koncertu. ${ }^{34}$ Akiste ste dostali program, ktorý som Vám poslal. Predovšetkým: Vaše dielo sa vel'mi vydarilo (a myslím si, že by ste boli s predvedením spokojný) a zožalo potlesk. Vd’aka Vášmu programu mi bolo dielo úplne jasné a aspoň smiem dúfat', že som ho uviedol na scénu podla Vašich zámerov. Avšak dojem, ktorý som mal už na začiatku pri štúdiu Vášho diela, že jeho poetický obsah je príliš detailný a t’ažko pochopitel'ný bez úplne presného programu, mi vel’a hudobníkov po predstavení potvrdilo. Myslím si, že by ste mali pri budúcich predvedeniach Vášho diela predoslat' vel'mi konkrétny básnický program; nemal som z Vašej strany žiadnu plnú moc, aby som ho zostavil z Vášho listu, bolo by to pre mňa aj obt’ažné, myslím si, že sa na to asi musíte odhodlat' sám. 
Ich bin mir, wie gesagt, jetzt vollständig klar über Ihr Stück und gefällt es mir ausserordentlich, hat mich von Probe zu Probe mehr interessiert und bin ich hocherfreut, als der Erste Ihren Namen in Deutschland in die Öffentlichkeit eingeführt zu haben. Schreiben Sie mir recht bald ein neues Stück und seien Sie aufs herzlichste gegrüßt

von Ihrem treu ergebenen

Richard Strauss

Die Noten erhalten Sie im September zurück. Brauchen Sie dieselben früher?

11

Weimar, 30. September 90

Lieber Herr Bella,

Herzlichen Dank für ihren liebenswürdigen Brief; bitte senden Sie mir sofort Ihr neues Werk; wenn ich irgend Gelegenheit haben werde, will ich es aufführen.

Mit herzlichem Gruss

Ihr aufrichtig ergebener

Richard Strauss

12

München, den $11-2-93$

Sehr geehrter Herr Musikdirektor!

Mein Sohn, welcher seit Anfang November, zur Kräftigung seiner Gesundheit sich im Urlaub befindet, hat mich beauftragt, alle Sendungen an ihn, welche mir von Weimar übermittelt werden zu öffnen, und im gegebenen Falle zu beantworten.

Ich erlaube mir Sie in Kenntnis zu setzen, daß mein Sohn sich von seiner Krankheit, welche er sich durch Überanstrengung im vorrigen Winter zugezogen hat, vollständig erholte, und sich jetzt einer vortrefflichen Gesundheit erfreut. Gegenwärtig ist er, nachdem er sich in Kairo ein Monat aufhielt, in Luxor - Oberegypten - und gedenkt bis Ende März dort zu bleiben, und will dann von dort seine Rückreise über Sicilien antreten, um Ende Juni wieder in Weimar sein zu können.

Sehr bedauern wird er, Ihrem Wunsche, in Betreff der deutschen Tonkünstler - Versammlung in München nicht dienstlich sein zu können, da er sich, auf ärztliche Anordnung, während seines Urlaubes aller geschäftlichen Arbeiten enthalten muß, folglich mit dem Comité in gar keiner Verbindung steht.

Gestatten Sie mir, daß ich mich der angenehmen Pflicht entledige, Ihnen für die Zusendung Ihrer geistreichen und gediegenen Analyse von "Wanderers Sturmlied“ im Namen meines Sohnes den herzlichsten Dank zu sagen.

Indem ich nochmal herzlich bedaure, Ihnen keine günstigere Nachricht geben zu können, zeichne ich mich mit bestem Grusse

Ihr ergebenster

Fr. (Franz) Strauss

Professor a. d. k. Akademie der Tonkunst 
Ako už bolo povedané, Vaše dielo je mi už úplne jasné a mimoriadne sa mi páči, od skúšky ku skúške ma zaujímalo čoraz väčšmi a vel'mi ma teší, že som ako prvý uviedol Vaše meno do povedomia v Nemecku. Napíšte mi čím skôr nové dielo a prijmite najsrdečnejšie pozdravy

od Vášho verne oddaného

Richarda Straussa

Noty Vám vrátim v septembri. Potrebujete ich skôr?

11 List Richarda Straussa Jánovi Levoslavovi Bellovi

Weimar, 30. septembra 1890

Milý pán Bella,

srdečná vd’aka za Váš láskavý list; prosím, ihned' mi pošlite svoje nové dielo; pri najbližšej príležitosti sa ho chystám uviest'.

So srdečným pozdravom

Váš úprimne oddaný

Richard Strauss

\section{List Franza Straussa Jánovi Levoslavovi Bellovi}

Mníchov, 11. februára 1893

Vážený pán hudobný riaditel!!

Môj syn, ktorý sa od začiatku novembra nachádza na dovolenke kvôli posilneniu svojho zdravia, ma poveril, aby som otvoril všetky jemu adresované zásielky, ktoré mi budú preposlané $z$ Weimaru, a prípadne na ne odpovedal.

Dovolujem si dat' Vám na vedomie, že sa môj syn úplne zotavil zo svojej choroby, ktorú si spôsobil minulú zimu prepínaním síl, a teraz sa teší výbornému zdraviu.

Momentálne sa po mesačnom pobyte v Káhire nachádza v Luxore - Horný Egypt - , kde chce zotrvat' do konca marca a potom chce nastúpit' odtial' na spiatočnú cestu cez Sicíliu tak, aby mohol byt' koncom júna znova vo Weimare.

Vel'mi bude lutovat', že nebude môct' poslúžit Vášmu želaniu ohl'adom zhromaždenia Nemeckého spolku hudobných umelcov v Mníchove, kedže sa na nariadenie lekára musí počas svojej dovolenky zdržat všetkých obchodných prác, a teda nie je s výborom v žiadnom spojení.

Dovolte mi splnit' si príjemnú povinnost' čo najsrdečnejšie Vám v mene môjho syna pod'akovat' za zaslanie Vašej duchaplnej a dôkladnej analýzy diela Wanderers Sturmlied.

Ešte raz zo srdca lutujem, že Vám nemôžem zaslat' priaznivejšiu správu, podpisujem s najsrdečnejším pozdravom

Váš najoddanejší

Fr. (Franz) Strauss

Profesor Královskej hudobnej akadémie 
Lieber Herr Bella!

Ich werde mich sehr freuen, Ihr Werk im Klavierauszuge kennenzulernen. Ob es mir gelingen würde, demselben am hiesigen Opernbazar (Hoftheater genannt) eine Aufführung zu ermöglichen, möchte ich leider heute schon bezweifeln. Es fehlt mir Vielgeplagtem die Zeit, Ihnen, der dem heutigen Kunstgeschäft so schön fern steht (in nicht allzulanger Zeit hoffe ich, Sie in dieser glücklichen Entfernung zu erreichen und dem öffentlichen Kunstleben auch den Rücken drehen zu können) die Gründe dazu eingehend auseinanderzusetzen. Für heute nur das Eine: dass bei der die kgl. Theater leitenden Behörde eine wahre Idiosynkrasie gegen "Wagnersche Textbücher" besteht, und dass die Geschäftsjuden, die den Opernmarkt heute halten, sich nach künstlerischen Rücksichten überhaupt nicht leiten lassen.

Sie können versichert sein, dass ich diese traurige Tatsache längst schwer empfinde, ohne die Macht zu haben als Einziger und Künstler gegen diesen Ring von Geschäftsinteressen, wie ihn das heutige Theater darstellt, ankämpfen zu können - mit Erfolg.

Ich verreise morgen auf 14 Tage! Bitte entschuldigen Sie die Eile dieses Schreibens und senden Sie mir Ihren Klavierauszug!

Die Nachricht vom Tode Ihres Töchterchens erfüllt mich mit innigster Teilnahme: ich bitte Sie, auch Ihrer Frau Gemahlin den Ausdruck meines wärmsten Beileids übermitteln zu wollen, und bleibe mit besten Grüssen

Ihr ergebenster

Richard Strauss

14

Grand Hotel St. Moritz,

St. Moritz-Dorf.

Direction C. Rueck.

29. 1. 12.

Verehrter Herr Bella!

Gratuliere herzlich zum talentvollen Sohn! Leider bin ich bis Mitte Mai auf Reisen und kann Sie daher wohl nicht bitten, mir die Compositionen Ihres Sohnes zu schicken!

Am 24. Februar aber bin ich in Budapest: kann ich vielleicht Ihren Sohn da sehen? Wenn nicht, schicken Sie mir seine Werke Mitte Mai nach Garmisch (Oberbayern).

Mit herzlichem Gruß

Ihr sehr ergebener

Dr. Richard Strauss 
13 List Richarda Straussa Jánovi Levoslavovi Bellovi

Charlottenburg, 12. októbra 1899

Milý pán Bella!

S vel'kou radostou sa oboznámim s klavírnym výtahom Vášho diela. ${ }^{35}$ Či by sa mi podarilo predstavit' ho $v$ tunajšom opernom bazári (zvanom Dvorné divadlo), o tom už dnes, žial', pochybujem. Mne, tažko skúšanému, chýba čas, aby som Vám, ktorý sa nachádzate tak pekne daleko od dnešného obchodu s umením (dúfam, že onedlho Vás budem môct' dostihnút $v$ tejto štastnej vzdialenosti a tiež sa obrátit chrbtom $\mathrm{k}$ verejnému umeleckému životu), podrobne vysvetlil dôvody. Pre dnešok azda len tolko: v úrade, ktorý spravuje král'ovské divadlá, existuje skutočná idiosynkrázia proti „wagnerovským libretám", a židovskí obchodníci, ktorí dnes ovládajú operný trh, sa vôbec neriadia umeleckými zretel'mi.

Uistujujem Vás, že už dávno t’ažko pocitujem túto smutnú skutočnost', bez toho, aby som mal moc ako jednotlivec a ako umelec úspešne bojovat proti tomuto kruhu obchodných záujmov, aký predstavuje dnešné divadlo.

Zajtra na 14 dní odchádzam! Prosím ospravedlňte chvat tohto listu a pošlite mi Váš klavírny výtah!

Správa o úmrtí Vašej dcérenky ${ }^{36}$ ma naplňa najúprimnejšou účastou: prosím Vás, aby ste odovzdali aj Vašej pani manželke vyjadrenie mojej najhlbšej sústrasti a ostávam s najsrdečnejšími pozdravmi

Váš najoddanejší

Richard Strauss

14 List Richarda Straussa Jánovi Levoslavovi Bellovi

Grand Hotel St. Moritz, St. Moritz-Dorf. Riaditel'stvo C. Rueck.

29. 1.1912

\section{Vážený pán Bella!}

Srdečne Vám gratulujem k talentovanému synovi ${ }^{37}$ Žial', do polovice mája som na cestách, a preto Vás zrejme nemôžem žiadat', aby ste mi poslali kompozície Vášho syna!

Avšak 24. februára budem v Budapešti: mohol by som sa s Vaším synom stretnút tam? Ak nie, pošlite mi jeho diela v polovici mája do Garmischu (Horné Bavorsko).

So srdečným pozdravom

Váš vel'mi oddaný

Dr. Richard Strauss

(Preklady z nemčiny do slovenčiny Zuzana Godárová) 
1 NOVÁČEK, Zdeněk: Korešpondencia Jána Levoslava Bellu s Milošom Ruppeldtom. In: Hudobnovedný sborník, roč. 1, 1953. Bratislava: Slovenská akadémia vied, 1953, s. $84-131$.

2 OREL, Dobroslav: Ján Levoslav Bella. K 80. narozeninám seniora slovenské hudby. Sborník Filosofické fakulty University Komenského v Bratislavě, roč. 2, 1924, č. 25 (8). Bratislava: Filosofická fakulta University Komenského s podporou Ministerstva školství a národní osvěty tiskem Státní tiskárny v Praze, 1924.

3 OREL, c. d., 1924, s. $118-154$.

4 ZAVARSKÝ, Ernest: Ján Levoslav Bella. Život a dielo. Bratislava: Vydavatel'stvo Slovenskej akadémie vied, 1955, s. 230.

5 Pozri napríklad: KRAUSE, Ernst: Richard Strauss: Gestalt und Werk. Leipzig: VEB Breitkopf \& Härtel, 1955; WERBECK, Walter: Richard Strauss. Handbuch. Stuttgart: J. B. Metzler; Bärenreiter, 2014; SCHMID, Mark-Daniel: The Richard Strauss Companion. Westport: Praeger Publishers, 2003; YOUMANS, Charles (ed.): The Cambridge Companion to Richard Strauss. Cambridge: Cambridge University Press, 2010.

6 OREL, c. d., 1924, s. 146 - 147; ZAGIBA, Franz: Johann L. Bella (1843-1936) und das wiener Musikleben. Wien: Verlag des Notringes der wissenschaftlichen Verbände Österreichs, 1955 , s. $46-47$.

7 OREL, c. d., 1924, s. 147 - 148; ZAGIBA, c. d., 1955 , s. $47-48$.

8 ZAGIBA, c. d., 1955 , s. $49-55$.

9 OREL, c. d., 1924, s. 148 - 149; ZAGIBA, c. d., 1955 , s. $48-49$.

10 OREL, c. d., 1924, s. 149; ZAGIBA, c. d., 1955, S. 55.

11 OREL, c. d., 1924, s. 149; ZAGIBA, c. d., 1955, s. 56.

12 Bernhard Stavenhagen (1860 - 1914), nemecký klavirista a skladatel', žiak Franza Liszta a autor viacerých klavírnych kompozícií, premiérovo uviedol okrem svojich diel aj skladby Richarda Straussa, Hansa Pfitznera, Arnolda Schoenberga, Gustava Mahlera, Clauda Debussyho, Maurica Ravela, Gabriela Faurého, Sergeja Tanejeva, Milija Balakireva. Nie je známe, že by uviedol aj Bellovu Sonátu $b$ mol.

13 OREL, c. d., 1924, s. 150 - 151; ZAGIBA, c. d., 1955 , s. $56-58$.

14 Strauss tu svoje skladby označuje pojmom „symfonická báseň“ (sinfonische Dichtung).
Gerald Abraham tvrdí, že Strauss tento pojem nikdy nepoužil, ale používal len pojem "Tondichtung". (ABRAHAM, Gerald: Stručné dejiny hudby. Bratislava: Hudobné centrum, 2003, s. 632.)

15 OREL, c. d., 1924, s. 153; ZAGIBA, c. d., 1955, S. 58.

16 KVĚT, Jindřich: Neznámý Bellův program symfonické básně Osud a ideál. In: Musikologie, roč. 1, 1938, s. 122 - 129. Redaktor Vladimír Helfert. Praha-Brno: Edice Melantrich - Pazdírek; ZAGIBA, c. d., 1955, s. 59 - 64.

17 List nezverejnil Orel vo svojej monografii (Orel poznal pravdepodobne len Fibichovu analýzu uverejnenú pred pražskou premiérou); po prvýkrát vyšiel v redakcii Vladimíra Helferta v brnianskom časopise Musicologie, roč. 1, 1938, Praha; Brno, s. 122 - 129. Tento závažný dokument tu vychádza po prvýkrát v slovenskom preklade.

18 OREL, c. d., 1924, s. 152; ZAGIBA, c. d., 1955, s. $64-65$.

19 ZAGIBA, c. d., 1955, s. 65.

20 OREL, c. d., 1924, s. $152-153$.

21 OREL, c. d., 1924, s. 153; ZAGIBA, c. d., 1955, s. $65-66$.

22 OREL, c. d., 1924, s. 154; ZAGIBA, c. d., 1955, s. $65-66$.

23 ZAVARSKÝ, c. d., 1955, s. 231. Riaditel' budapeštianskej opery Raoul Mader (tiež Rezső Máder, 1856 - 1940) bol bratislavský rodák, absolvent Viedenského konzervatória, skladatel' hudobno-javiskových diel.

24 Strauss tu vymenúva tieto svoje rané diela: Sonáta pre violončelo a klavír $F$ dur op. 6 (1883, Ed. Joseph Aibl, n. d.), Klavírne kvarteto c mol op. 13 (1884, Ed. Joseph Aibl 1886), Sonáta pre husle a klavír Es dur op. 18 (1887, Ed. Joseph Aibl 1888), Wandrers Sturmlied op. 14 (1885, Ed. Joseph Aibl 1890), Symfónia č. 2 fmol pre orchester op. 12 (1884, Ed. Joseph Aibl 1885), Aus Italien pre orchester op. 16 (1886, Ed. Joseph Aibl 1887), Acht Gedichte aus "Letzte Blätter" pre hlas a klavír op. 10 (1885, Ed. Joseph Aibl 1887), Fünf Lieder pre hlas a klavír op. 15 (1886, Sechs Lieder op. 17, 1887), Sechs Lieder op. 19 (1888, Ed. Hamburg, D. Rahter 1888).

25 Franz Liszt: Prometheus, symfonická báseň pre orchester, 1855.

26 Georg Friedrich Händel: Judas Maccabaeus, oratórium 1746; Felix Mendelssohn: Elijah, oratórium op. 70, 1846, Robert Schumann: Das Paradies und die Peri, oratórium op. 50, 1843. 
27 Ludwig van Beethoven: Coriolanus, predohra pre orchester op. 62, 1807; Leonora, predohra č. 3 op. 72b, 1806.

28 Richard Strauss: Macbeth, Tondichtung pre vel'ký orchester op. 23, 1888 (v čase písania tohto listu dielo ešte nebolo predvedené), Don Juan, Tondichtung pre vel'ký orchester op. 20, 1888 (v čase písania tohto listu dielo ešte nebolo dokončené).

29 Richard Strauss tu má na mysli Wagnerove texty Über Franz Liszts Symphonische Dichtungen, 1857 (listy Carolyne Sayn-Wittgensteinovej), V, III a Über die Ouvertüre, 1841, I, VII.

30 Heinrich Viehoff cituje Goetheho dielo nepresne, správny názov je Dichtung und Wahrheit [Poézia a pravda].

31 Doplnené podl'a http://www.zeno.org/ Literatur/M/Goethe,+Johann+Wolfgang/ Autobiographisches/Aus+meinem+Leben.+Dichtung+und+Wahrheit/Dritter+Teil/ Zw\%C3\%B6lftes+Buch(pozn. prekl.).

32 GOETHE, Johann Wolfgang: Pútnikova pieseň v búrke. In: Faustovské reflexie. Preklad Móric Mittelmann Dedinský. Bratislava: Tatran, 1982, s. 45 - 48. Tu uvádzame iba verše použité v Straussovej skladbe.

33 Richard Strauss: Tod und Verklärung, Tondichtung für grosses Orchester op. 24, 1889. Premiéra bola 21. 6. 1890 v mestskom divadle $v$ Eisenachu. Orchester des Tonkünstlerfest dirigoval autor.
34 Na koncerte 22. mája 1890 v Eisenachu Richard Strauss uviedol okrem Bellovej skladby Osud a ideál aj 4. symfóniu (1885) Eugena d'Alberta, Kaiser-Marsch (1871) Richarda Wagnera a tenorovú áriu z opery Hectora Berlioza Benvenuto Cellini (1836 - 1838, ed. 1886).

35 Strauss si s najväčšou pravdepodobnostou pýta klavírny výtah Bellovej opery Kováč Wieland, ktorá teda už bola dokončená v klavírnom výtahu, alebo ju autor práve dokončoval.

36 Irmgard Bella bola najmladšia dcéra Augusty Luisy Márie Bellovej a Jána Levoslava Bellu, ktorí uzavreli manželstvo v Sibini 9. 10. 1882. Irmgard sa narodila 18. júna 1892 a zomrela roku 1899 na šarlach. $Z$ bolesti nad smrtou dcérky vznikla roku 1899 sólová ária pre soprán a orchester Bergglocke, zhudobňujúca báseň Michaela Alberta (1836 - 1893) Vianoce na cintoríne (Weihnacht auf dem Friedhof).

37 Rudolf Bella (1890 - 1973) v tejto dobe študoval vo Viedni kompozíciu u Eusebia Mandyczewského a dirigovanie u Franza Schalka. Neskôr pôsobil v rokoch 1921 - 1924 v ukrajinskom Černivci. Roku 1926 sa usadil vo švajčiarskom meste Romanshorn. Rozsiahla skladatel'ská pozostalost’ Rudolfa Bellu sa nachádza v knižnici švajčiarskej univerzity $v$ Lausanne.

\section{BIBLIOGRAFICKÉ ÚDAJE}

Listy - Ján Levoslav Bella / Richard Strauss (Orel, s. 146 - 154; Zagiba, s. 46 - 66; Květ, s. 122 - 129)

1) München - 27. 8. 1888 - (Orel, s. 146 - 147; Zagiba, s. 46 - 47)

2) München - 2. 12. 1888 - (Orel, s. 147 - 148; Zagiba, s. 47 - 48)

3) Bella: Goethe: Wandrers Sturmlied (Richard Strauss, op. 14) - (Zagiba, s. 49 - 55)

4) München - 16.12. 1888 - (Orel, s. 148 - 149; Zagiba, s. 48 - 49)

5) München - 21. 12. 1888 - (Orel, s. 149; Zagiba, s. 55)

6) Weimar - 25. 10. 1889 - (Orel, s. 149; Zagiba, s. 56)

7) Wien - 3.3. 1890 - (Orel, s. 150 - 151; Zagiba, s. 56 - 58)

8) Weimar - 19.4. 1890 - (Orel, s. 153; Zagiba, s. 58)

9) Hermannstadt/Sibiu - 25. 4. 1890 - (Zagiba, s. 59 - 64; Květ, s. 122 - 129)

10) München - 11. 7. 1890 - (Orel, s. 152; Zagiba, s. 64 - 65)

11) Weimar - 30. 9. 1890 - (Zagiba, s. 65)

12) München - 11. 2. 1893 - píše otec Franz Strauss - (Orel, s. 152 - 153)

13) Charlottenburg - 12. 10. 1899 - (Orel, s. 153; Zagiba, s. 65 - 66)

14) Grand Hotel St. Moritz, St Moritz-Dorf - 29. 1. 1912 - (Orel, s. 154; Zagiba, s. 65 - 66) 
PRAMENE

KVĚT, Jindřich: Neznámý Bellův program symfonické básně Osud a ideál. In: Musikologie, roč. 1, 1938, s. 122 - 129. Redaktor Vladimír Helfert. Praha - Brno: Edice Melantrich - Pazdírek.

OREL, Dobroslav: Ján Levoslav Bella. K 80. narozeninám seniora slovenské hudby. Sborník Filosofické fakulty University Komenského v Bratislave, roč. 2, 1924, č. 25 (8). Bratislava: Filosofická fakulta University Komenského s podporou Ministerstva školství a národní osvěty tiskem Státní tiskárny v Praze, 1924.

ZAGIBA, Franz: Johann L. Bella (1843 - 1936) und das Wiener Musikleben. Wien: Verlag des Notringes der wissenschaftlichen Verbände Österreichs, 1955, kap. 3. „Bella als Vorkämpfer des jungen Richard Strauss : Strauss' künstlerisches Credo in seinen Briefen an Bella", s. 46 - 66.

ZAVARSKÝ, Ernest: Ján Levoslav Bella. Život a dielo. Bratislava: Vydavatel'stvo Slovenskej akadémie vied, 1955.

SUMMARY

The Correspondence of Ján Levoslav Bella and Richard Strauss

In the course of several decades of the second half of the $19^{\text {th }}$ century and the first half of the $20^{\text {th }}$ century both Ján Levoslav Bella and Richard Strauss worked as musicians - composers and conductors - for German communities. Fourteen letters exchanged between them in the period of August 27, 1888 and January 29, 1912 have been preserved to this day, dealing mostly with practical problems arising in their work. The letters accompany the presentation of Richard Strauss' cantata Wandrers Sturmlied, Op. 14 in Sibiu, Transylvania, under the baton of Ján Levoslav Bella, and the Eisenach (Germany) performance of Bella's symphonic poem The Destiny and Ideal on April 25, 1890 conducted by Richard Strauss, and they shed light on both events. They represent in themselves a weighty evidence of the transformation of opinions on composer's art and establish the ideal of programme music, which for both composers-Kapellmeisters stood for a revolutionary artistic concept. The preserved letters are published for the first time in their entirety and paralelly in both languages - original German and translated Slovak version.

Keywords

Ján Levoslav Bella, The Destiny and Ideal, Richard Strauss, Wandrers Sturmlied, correspondence

Prepis notových ukážok na s. 172 - 177 Peter Hanzel. 